MAJOR U.S. WEAPONS PRODUCTION FACILITIES 1,2

C. T. Garten, Jr.

Ecological and Earth Sciences Section

Environmental Sciences Division

Oak Ridge National Laboratory

P.O. Box 2008

Oak Ridge, Tennessee, USA 37831-6038.

D. M. Hamby

Department of Environmental and Industrial Health

School of Public Health

University of Michigan

Ann Arbor, Michigan, USA

R. G. Schreckhise

Environmental Science Program

Washington State University Tri-Cities

Richland, Washington, USA

1This manuscript is based on work performed at Oak Ridge National Laboratory, managed for the U. S. Department of Energy under contract DE-AC05-960R22464 with Lockheed Martin Energy Research Corporation and also, in part, by the U.S. Nuclear Regulatory Commission through a grant to the National Council on Radiation Protection and Measurements, Bethesda, Maryland.

2Publication No. \$\$\$, Environmental Sciences Division, ORNL.

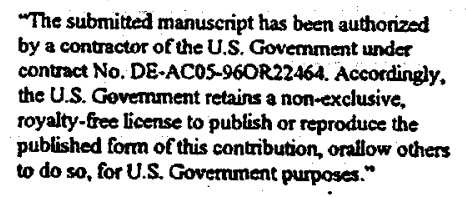




\section{RADIOCESIUM DISCHARGES AND SUBSEQUENT ENVIRONMENTAL TRANSPORT AT THE MAJOR U.S. WEAPONS PRODUCTION FACILITIES}

Garten, C. T., Jr. ${ }^{1}$, D. M. Hamby'2, and R. G. Schreckhise ${ }^{3}$

${ }^{1}$ Ecological and Earth Sciences Section, Environmental Sciences Division, Oak Ridge National Laboratory, Oak Ridge, Tennessee, USA

2Department of Environmental and Industrial Health, School of Public Health, University of Michigan, Ann Arbor, Michigan, USA

${ }^{3}$ Environmental Science Program, Washington State University Tri-Cities, Richland, Washington, USA

\section{ABSTRACT}

Radiocesium is one of the more prevalent radionuclides in the environment as a result of weapons production related atomic projects in the United States and the former Soviet Union. Radiocesium discharges during the 1950's account for a large fraction of the historical releases from U.S. weapons production facilities. Releases of radiocesium to terrestrial and aquatic ecosystems during the early years of nuclear weapons production provided the opportunity to conduct multidisciplinary studies on the transport mechanisms of this potentially hazardous radionuclide. The major U.S. Department of Energy facilities (Oak Ridge Reservation in Tennessee, Hanford Site near Richland, Washington, and Savannah River Site near Aiken, South Carolina) are located in regions of the country that have different geographical characteristics. The facility siting provided diverse backgrounds for the development of an understanding of environmental factors contributing to the fate and transport of radiocesium. In this paper, we summarize the significant environmental releases of radiocesium in the early years of weapons production and then discuss the historically significant transport mechanisms for ${ }^{137} \mathrm{Cs}$ at the three facilities that were part of the U.S. nuclear weapons complex.

Revision Date: 14 September 1999 


\section{INTRODUCTION}

The "nuclear weapons complex" of the United States was, at its peak, made up of 16 major sites across the nation (DOE 1995, 1997). Over the 50 years of its existence, this complex built tens of thousands of nuclear devices. With the ending of the Cold War, the U.S. Department of Energy (DOE) was left with a nuclear weapons complex covering more than $9.3 \times 10^{9} \mathrm{~m}^{2}$ of land in more than ten states (DOE, 1995). The production of nuclear weapons generated both radiological and chemical pollutants and has contaminated particular areas in the U.S. that now require environmental restoration. The environmental management task is one that will remain for decades, with the most urgent and high-risk facilities receiving priority for environmental cleanup.

The primary radiological environmental contaminants that are being addressed at major weapons facilities across the U.S. are the transuranic elements and long-lived fission and activation products. One of the more prominent contaminants is cesium-137 $\left({ }^{137} \mathrm{Cs}\right)$, a highyield fission product with a radioactive half-life of 30 years. Because of its relative magnitude, ease of detection, and its relative potential to cause harm to humans through gamma ray emissions, ${ }^{137} \mathrm{Cs}$ has received a great deal of past attention and is probably one of the most thoroughly studied radionuclides from the standpoint of environmental fate and transport.

In this paper, we present information on the discharge and transport characteristics of radiocesium released to the environment at three facilities that played major roles in the production of U.S. nuclear weapons. These facilities are the Oak Ridge Reservation in Tennessee, the Hanford Site in Washington, and the Savannah River Site in South Carolina. Our discussion is centered on site characteristics and data on site-specific releases of radiocesium to the environment, as well as some historical information on early environmental studies. We have focused on the early years of U.S. weapons production (1945-1969), with a few interspersed comments on the current situation. Radiocesium's high fission yield and ease of detection made it a prime candidate for early radioecological investigations. It was soon realized that ${ }^{137} \mathrm{Cs}$ could be used to trace the transport of other radionuclides that had a high affinity for binding to soil particles (silts and clays).

\section{SITE ROLES IN WEAPONS PRODUCTION}

Approximately two-thirds of the radioactive waste legacy managed by DOE originated from the production of nuclear weapons (DOE, 1997). Most of this radioactive waste legacy is located at DOE facilities that were involved with chemical separation operations for the production of nuclear weapons (i.e., Hanford and Savannah River). As of 1995, the total amount of radioactivity stored and disposed of at Oak Ridge, Hanford, and Savannah River was approximately 4.4,358, and $542 \mathrm{MCi}$, respectively (DOE, 1997). Table 1 provides a comparison of the major weapons-production activities that took place at the three sites during full-scale operations in the 1950s. Figure 1 shows the timing of some milestone events at each site in the 1940s and 50s. 


\section{Oak Ridge}

Three facilities ( $\mathrm{Y}-12, \mathrm{~K}-25$, and X-10) were located at Oak Ridge in 1943 as part of the U.S. mission to develop and manufacture the first atomic bombs (i.e., the Manhattan Project). In the early years of its operation, the Y-12 Plant was used for the enrichment of ${ }^{235} \mathrm{U}$ by electromagnetic separation. Later $\mathrm{Y}-12$ was used for the production and fabrication of nuclear weapons components (making both $U$ and lithium deuteride weapons parts). The $\mathrm{K}-25$ Site was a gaseous diffusion plant for the production of enriched uranium. The X-10 Site, now Oak Ridge National Laboratory (ORNL), was a research and development center. It was the site of a graphite reactor that served as the prototype for plutonium ( $\mathrm{Pu}$ ) production reactors concurrently constructed at Hanford.

\section{Hanford}

The Hanford Site was acquired by the U.S. government in 1943 for the construction and operation of facilities to produce $\mathrm{Pu}$ for the atomic weapons program in World War II. Up until 1987, the Site was dedicated primarily to the production of $\mathrm{Pu}$ for national defense purposes and the management of the associated wastes, research and development on advanced energy sources, and waste disposal technologies. Starting in about 1987, the mission was redirected away from $\mathrm{Pu}$ production and focused on the clean up of contaminated areas and decommissioning of most of the nuclear facilities on the site. During the 1950s, Hanford included a variety of facilities for fuel and target fabrication, irradiation of fuel assemblies, chemical separations, and weapons component fabrication (Table 1).

\section{Savannah River}

Originally established in the early 1950s, the Savannah River Site was also developed as part of the U.S. nuclear weapons complex. Construction at the site began in February of 1951, with the first facility (the heavy water plant) becoming operational in August 1952. The first of five reactors achieved criticality in December, 1953, with the other four coming online by March, 1955 (Bebbington, 1990). Throughout its production years, the Savannah River Site maintained, at one time or another, one fuel fabrication facility, a heavy water production plant, five nuclear reactors, two separations facilities, and various waste management facilities (Table 1). Historically, the reactors, separations facilities, and waste facilities were the primary sources from which radiocesium entered the environment. The Site played a major role in the production and processing of nuclear materials, especially heavy water and tritium $\left({ }^{3} \mathrm{H}\right)$, until the end of the Cold War in 1991. 


\section{COMPARISON OF SITE CHARACTERISTICS}

\subsection{Geographic Locations}

Oak Ridge. The Oak Ridge Reservation is located in east Tennessee at $35^{\circ} 55^{\prime} \mathrm{N}$ latitude and $84^{\circ} 19^{\prime} \mathrm{W}$ longitude (Figure 2). The 14,000-ha Reservation is bordered on the north by the City of Oak Ridge. The Clinch River, including Melton Hill Lake, borders the eastern, southern, and western boundaries of the reservation. Approximately $40 \mathrm{~km}$ to the east of the Oak Ridge Reservation lies the metropolitan city of Knoxville, Tennessee. Temperate deciduous forest (oak, hickory, and other hardwoods) was the dominant vegetation type on the Reservation in the 1950s although large areas of loblolly pine were planted between 1947 and 1956 (Coobs and Gissel, 1986).

Hanford. The Hanford Site (Figure 3) occupies an area of $1450 \mathrm{~km}^{2}$ within the semi-arid Mid-Columbia Basin of the Columbia Plateau in south central Washington state. About $6 \%$ of the land area has been disturbed and is actively used. Land areas to the west, north, and east of the site are principally range and irrigated farmlands. The Columbia River flows eastward through the northern part of the site and then turns south, forming part of the eastern boundary. The Yakima River borders a small length of the southern portion of the site and flows into the Columbia River in the southern portion of the City of Richland. The cities of Richland, Kennewick, and Pasco (i.e., the Tri-Cities) constitute the nearest population center and are located south and southeast of the site. Vegetation at the site is classified primarily as a shrub-steppe by Daubenmire (1970).

Savannah River. The Savannah River Site encompasses nearly $800 \mathrm{~km}^{2}$ in South Carolina, on the eastern shore of the central Savannah River, approximately $40 \mathrm{~km}$ southeast of Augusta, Georgia, and 250 river-km upstream from the Atlantic Ocean (Figure 4). The site lies on South Carolina's Upper Coastal Plain, at $33^{\circ} 00^{\prime} \mathrm{N}$ latitude and $81^{\circ} 40^{\prime} \mathrm{W}$ longitude. Nearly $90 \%$ of the Savannah River Site is now forested (Pinder et al., 1998), with the majority of the remaining land area characterized by habitats ranging from very sandy hilltops to continually flooded swamps. At the time construction began in 1951, land use on the site was a mixture of agriculture (mostly small farms) and forestry.

\subsection{Climate}

Oak Ridge, Hanford, and Savannah River have markedly different climates (Figure 5). A comparison of the annual climatological data is presented in Table 2. The primary distinction between the three sites is the cool-arid climate of Hanford in the Pacific northwest versus the warm-humid climate of Oak Ridge and Savannah River in the southeastern U.S.

Oak Ridge. The climate in east Tennessee is classified as temperate and humid (Hamilton et al., 1996; Hamilton et al., 1997). Winter (December through February) is the wettest period of the year and autumn (September and October) is the driest. Annual evapotranspiration 
(ET) at this site is approximately $53 \%$ of the mean annual precipitation (TVA, 1972). Highest ET occurs during the growing season and soil moisture deficits frequently occur during the summer when ET exceeds precipitation.

Hanford. The climate at Hanford is greatly influenced by the Cascade Mountains to the west which contribute to a rain shadow effect and also serve as a source of cold air drainage, which has a considerable effect on the wind regime. Typically, wind speeds are lowest during the winter months, averaging 10 to $11 \mathrm{~km} \mathrm{~h}^{-1}$ and highest during summer, averaging 14 to $16 \mathrm{~km} \mathrm{~h}^{-1}$ (Cushing et al., 1992). During the summer, northwesterly winds frequently reach $50 \mathrm{~km} \mathrm{~h}^{-1}$. Average annual precipitation at Hanford is approximately $20 \mathrm{~cm}$ and most of the precipitation occurs during the winter.

Savannah River. The climate of the central Savannah River area is classified as humid and subtropical. This site is characterized by mild winters. Rainfall is evenly distributed throughout the year. Except for the river valley itself, there are no unusual topographic features that would significantly influence the general climate. Potential ET at the Savannah River Site is higher than that at Oak Ridge (Table 2).

\subsection{Geology and Hydrology}

Oak Ridge. Thrust faulting and erosion processes produced a series of parallel valleys and ridges in east Tennessee (known as the Ridge and Valley Province) that run in a southwestnortheast direction across the Oak Ridge Reservation. Generally, ridges are formed of siltstone, sandstone, and cherty dolomite; shale (Conasauga Group) and limestone-rich formations underlie the valleys. Additional details on geology can be found in Hatcher et al. (1992). The acidic soils ( $\mathrm{pH} 4.5-5.7$ ) at this site have a high silt and clay content. The primary minerals in the weathered shales are illite and vermiculte (Coobs and Gissel 1986). The primary source of groundwater in the vicinity of the Oak Ridge Reservation is the Knox Aquifer which consists of dolostone and limestone. Shallow water at 3 to $15 \mathrm{~m}$ depth is the "groundwater" of importance on the Oak Ridge Reservation. Topography in the vicinity of Oak Ridge, along with existing geology, dictates that almost all groundwater flow is shallow. An aquitard underlies many of the waste disposal sites at Oak Ridge and most of the precipitation that infiltrates soil is lost through lateral runoff to surface streams (Solomon et al. 1992; Jago et al., 1997). About $45 \%$ of annual precipitation occurs as runoff each year (approximately $63 \mathrm{~cm}$ ). At this site, subsurface flow paths for migrating contaminants in groundwater tend to be short (Huff et al., 1998).

Hanford. Principal geologic units beneath the Hanford Site include, in ascending order, the Columbia River Basalt Group (basaltic lava flows), the Ringold Formation (ancient river and lake sediments), and a series of deposits informally referred to as the Hanford formation (mostly coarse gravel and sand). These units are covered locally by surface alluvial or windblown deposits. Hajek (1966) described 15 different soil types at Hanford varying from sand to silty and sandy loam. Both confined and unconfined aquifers are present. In general, the unconfined or water-table aquifer is located in the Ringold Formation and 
glaciofluvial sediments, as well as some more recent alluvial sediments in areas adjacent to the Columbia River (Gephart et al., 1979). This relatively shallow aquifer has been affected by wastewater disposal at Hanford (Graham et al., 1981). Thus, it is carefully monitored. The unconfined aquifer receives little, if any, recharge from precipitation on the Hanford Site because of a high rate of ET, but it does receive recharge from several other sources (Graham et al., 1981). The Columbia River, which varies in width from approximately 300 to $1000 \mathrm{~m}$, is the dominant surface water feature at Hanford. It originates in the mountains of eastern British Columbia, Canada, and drains a total area of approximately $70800 \mathrm{~km}^{2}$ enroute to the Pacific Ocean. Flow of the Columbia River is regulated by 11 dams, 7 upstream and 4 downstream of the Site. Vast Columbia River floods have occurred in the past (Cushing et al., 1992). Major floods were caused by the rapid melting of winter snowpack augmented and/or caused by above-normal rainfall. The probability of flooding has been reduced significantly by the upstream dams. Average annual runoff is approximately 2 to $3 \mathrm{~cm}$.

Savannah River. The Savannah River Site is situated in the Southern Bottomland Hardwood Swamp region on the southeastern coastal plain of South Carolina. The topography is relatively flat with a slight downward slope toward the Savannah River which drains to the Atlantic Ocean (Figure 4). Annual runoff is approximately $35 \mathrm{~cm} /$ year. The region's main features are river swamps which are rarely more than $8 \mathrm{~km}$ wide. Sandy surface soils play a major role in cesium transport at this site. Underlying the sandy surface soils are older sandstones, metamorphic, and igneous rocks (WSRC, 1997). The sandy sediments of the Coastal Plain contain several productive aquifers, separated by clay-rich units that drain into the Savannah River, its tributaries, and the Savannah River swamp. The underlying rocks are nearly impermeable and are not a major water source. Groundwater beneath the Savannah River Site flows slowly, at rates ranging from approximately 0.1 to $100 \mathrm{~m}$ per year. The depth to the water table is approximately 40 meters at the highest surface elevations, with the average for the sampling wells on site being about 20 to $25 \mathrm{~m}$ (Heirgesell, 1999).

\section{HISTORICAL PERSPECTIVES ON SOURCES AND ORIGINS OF RADIOCESIUM}

\section{Oak Ridge}

Radiocesium has been an important radiological contaminant in aquatic and terrestrial ecosystems at Oak Ridge, primarily associated with the Oak Ridge National Laboratory. Past atmospheric releases of radiocesium at Oak Ridge are negligible compared to releases originating from the disposal of solid and liquid radioactive wastes. The Laboratory's early mission (i.e., research and development on the production and the recovery of radioactive isotopes) generated large volumes of radioactive waste. In the 1940s, the disposal of liquid radioactive wastes generated by $\mathrm{Pu}$ and $\mathrm{U}$ recovery soon exceeded ORNL's limited storage facilities (Spalding, 1987). Following dilution of the waste with large volumes of nonradioactive process water, supernatants produced from the treatment of liquid radioactive wastes (by precipitation) were discharged to White Oak Creek, a small tributary to the south of the Laboratory (Figure 2). Waste treatment measures were implemented at 
the inception of ORNL in 1943 to abate contamination of the White Oak Creek Watershed, which drains an area of about $17 \mathrm{~km}^{2}$ before entering the Clinch River.

Early measures to abate environmental releases of radionuclides at Oak Ridge included construction of:

- waste settling basins at ORNL (i.e., Pond 3513 and 3524),

- an intermediate holding pond on the White Oak Creek floodplain, and

- White Oak Lake Dam at a point along White Oak Creek approximately $1 \mathrm{~km}$ upstream from its discharge in to the Clinch River (Figure 2).

The function of these impoundments was to provide for settling of suspended solids that contained radiocesium and other particle-reactive radionuclides and to allow continued decay of short-lived isotopes. Estimates of radiocesium inventories in these impoundments range from approximately $100 \mathrm{Ci}(3.7 \mathrm{TBq})$ to $800 \mathrm{Ci}(30 \mathrm{TBq})$ (Table 3). Most of the radiocesium resides in the sediments of a former retention pond on White Oak Creek and in the sediments of White Oak Lake which, from 1944 to 1955 , served as the final settling basin for radioactive and chemical effluents discharged from ORNL to the Clinch River. At least half of this radiocesium inventory may have disappeared due to radioactive decay.

The generation of liquid radioactive wastes at Oak Ridge peaked in the 1950 s and the Laboratory began construction on a series of waste pits and trenches (Stow and Serne, 1999) for land disposal of radioactive concentrates produced by an evaporator treatment facility built in 1949 (Figure 1). The evaporator treatment facility accomplished a 27:1 volume reduction in liquid radioactive wastes from laboratory operations (Spalding, 1987). The design objective of the pits and trenches used from 1951 to 1965 was to allow the seepage of wastes through a shale (Conasauga Group) formation that strongly retained nonexchangeable radionuclides. The retention for radiocesium was approximately 75 to $80 \%$ (Stow and Serne 1999). Approximately $160000 \mathrm{~m}^{3}$ of radioactive liquid wastes, including about $640 \mathrm{kCi}(24 \mathrm{PBq})$ of ${ }^{137} \mathrm{Cs}$, were disposed of through the use of the pits and trenches at Oak Ridge (Table 4). In the late 1950s, research was begun at ORNL on deep (i.e., 200 to $300 \mathrm{~m}$ ) subsurface injection of liquid radioactive waste. From 1964 to 1983, approximately $684 \mathrm{kCi}(25 \mathrm{PBq})$ of ${ }^{137} \mathrm{Cs}$ were disposed of at ORNL's hydrofracture facility by injecting mixtures of grout and intermediate level liquid radioactive waste into bedding planes and fractures in Conasauga shale formations that underlie the White Oak Creek Watershed (Coobs and Gissel, 1986; Myrick and Stow, 1987).

The main source of radiocesium $\left({ }^{137} \mathrm{Cs}\right)$ in contaminated areas southwest of ORNL (Figure 2) was the discharge of liquid radioactive wastes from laboratory operations during the 1940s and 1950s to various impoundments and White Oak Creek. Radiocesium, adsorbed to particles, settled in impoundments and along the floodplains of White Oak Creek Watershed (Lomenick and Gardiner, 1965). Pits, trenches and impoundments effectively retained ${ }^{137} \mathrm{Cs}$ through fixation by illitic clays. The estimated annual discharge from the White Oak Creek Watershed to the Clinch River illustrates the release history of radiocesium at Oak Ridge 
from 1949 to 1995 (Figure 6). Estimated annual releases of radiocesium at White Oak Lake Dam ranged from approximately $170 \mathrm{Ci}(6.3 \mathrm{TBq})$ to $0.2 \mathrm{Ci}(0.0074 \mathrm{TBq})$. Records are not available for releases of radiocesium prior to 1949. Since 1949, the total cumulative release of radiocesium from Oak Ridge to the Clinch River has been about $703 \mathrm{Ci} \mathrm{(26} \mathrm{TBq)} \mathrm{(Clapp} \mathrm{et}$ al., 1996).

\section{Hanford}

Three graphite-moderated, single-pass, Pu-production reactors were operating at Hanford by the end of World War II. Each reactor was cooled with water (approximately 114000 $\mathrm{L} / \mathrm{min}$ ) taken from the Columbia River (DOE, 1997). The water was pumped from the river, treated, passed through the reactors, and passed through retention basins where it was held up a few hours before being discarded back into the river. Beginning in 1948, five additional reactors were built at Hanford. Except for their greater power outputs, they were very similar to the original three reactors. A ninth production reactor (N Reactor) began operating in 1963, however it did not discharge cooling water directly into the river. The last single-pass reactor was shut down in 1971 and N Reactor in 1986 (DOE, 1997).

Most of the radioactive materials disposed of or stored at Hanford were created by the 9 production reactors. Radioactive materials were present in the water discharged from the single-pass reactors to the river. The radionuclides were formed by:

- neutron activation of ambient elements in the cooling water,

- neutron activation of elements in the materials used for the process tubes, fuel cladding, and other materials in the reactor core, and

- ruptured fuel elements.

Since it is a fission product, any ${ }^{137} \mathrm{Cs}$ present in the Columbia River from Hanford operations was from ruptured reactor fuel elements. However, according to Heeb and Bates (1994), even though there were approximately 2006 fuel element failures, the leaks were small and the cooling water from the reactor was normally diverted away from the river. Accordingly, they did not include any values for ${ }^{137} \mathrm{Cs}$ in their list of estimated annual releases of radionuclides from the reactors to the Columbia River for the years 1944 through 1971. Since the releases from Hanford's facilities were diverted to on-site locations, most of the ${ }^{137} \mathrm{Cs}$ observed in aquatic organisms collected from the Columbia River was probably from worldwide fallout sources. This is basically consistent with the findings of Wells (1994) and Beasley and Jennings (1984). Wells (1994) found that the concentration of ${ }^{137} \mathrm{Cs}$ in sediment collected in the Columbia River above Hanford was similar to that collected below the site. Beasley and Jennings (1984) concluded that approximately $75 \%$ of the ${ }^{137} \mathrm{Cs}$ in the McNary pool sediment (i.e., the first dam on the Columbia down river from the site) was from world-wide fallout and the remaining $25 \%$ from Hanford operations. From the latter data, we estimate the total off-site release of ${ }^{137} \mathrm{Cs}$ at Hanford to be about $65 \mathrm{Ci}(2.4 \mathrm{TBq})$. 
Most historical releases of radiocesium at Hanford were to waste disposal sites in the terrestrial environment and not to the atmosphere. Some radiocesium was released to the atmosphere during fuel reprocessing operations. According to Napier (1992), a total of approximately $42 \mathrm{Ci}(1.6 \mathrm{TBq})$ of ${ }^{137} \mathrm{Cs}$ was released to the atmosphere from the separation facilities at Hanford between 1945 and 1972. However, the primary repository of radiocesium at Hanford has been in the "200 Areas" where the majority of the site's waste disposal facilities (e.g., liquid-waste ponds, cribs, trenches, tanks and solid-waste burial grounds) are located and which, collectively, cover about $16 \mathrm{~km}^{2}$ (Anderson, 1974). More than $28 \mathrm{MCi}(1 \mathrm{EBq})$ of ${ }^{137} \mathrm{Cs}$ have been disposed of and stored in Hanford's 200 Areas since operations began in 1944, most of it stored in more than 150 single- and double-shelled tanks (NAS, 1978). Leaks at the tank farms have released more than $40 \mathrm{kCi}(1.5 \mathrm{PBq})$ of ${ }^{137} \mathrm{Cs}$ into underlying glaciofluvial deposits and the Ringold formation (NAS, 1978). The largest quantities of radiocesium had to be disposed of and/or stored in Hanford's 200 Areas during the 1950s because this was when Pu production was at its highest. It is also when most of the fuel elements ruptured because the reactors were running at higher energy levels and higher temperatures leading to fuel element failures and radiocesium releases to the environment.

Besides storage of radioactive wastes in tanks, contaminated process water and liquid wastes were historically discharged to cribs, trenches, french drains, ditches, and ponds. During 30 years of Hanford operations, approximately 500 million $\mathrm{m}^{3}$ of liquid waste were percolated into the ground including more than $40 \mathrm{kCi}(1.5 \mathrm{PBq})$ of ${ }^{137} \mathrm{Cs}$ (NAS, 1978). Land disposal in the 1950s was designed to allow the liquid wastes to percolate into the ground where the soil reactions removed the ${ }^{137} \mathrm{Cs}$, and most other contaminants, before they reached ground water. The cribs were essentially leach fields covered by various depths of soil. The trenches were covered with soil after receiving waste materials. The french drains were usually covered with metal structures. The ditches and ponds were left open, providing access to plants and animals, including fish. Contaminated solid wastes were disposed of in burial grounds.

\section{Savannah River}

Most historical releases of radiocesium at the Savannah River Site were to aquatic and terrestrial environments and not to the atmosphere. Historical releases of radiocesium to the atmosphere total approximately $3.5 \mathrm{Ci}(0.13 \mathrm{TBq})$, effectively all of which entered the atmosphere from the separations facilities (WSRC, 1991; Carlton et al., 1992). Similar to practices at other DOE sites, radioactive wastes from reactors and separations facilities were discharged to streams and seepage basins. Releases to streams were primarily from $P$ and $R$ reactors and were "routine". The major release $(788 \mathrm{Ci})$ to seepage basins occurred in 1957 and was caused by the failure of an experimental fuel tube. About $63 \mathrm{Ci}(2.3 \mathrm{TBq})$ and $900 \mathrm{Ci}$ (33 $\mathrm{TBq}$ ) of radiocesium were released to streams and to seepage basins, respectively, from 1955 to 1959 at the Savannah River Site (Carlton et al. 1992). The Savannah River Site also has a large inventory of radiocesium in sub-surface, high-level, radioactive liquid waste storage tanks (Table 5). 
The primary impact of radiocesium releases at the Savannah River Site is to on-site surface water streams in the form of ${ }^{137} \mathrm{Cs}$. Total aqueous releases of radiocesium to streams and seepage basins are estimated at approximately $2570 \mathrm{Ci}(95 \mathrm{TBq})$. About $75 \%$ of total aqueous releases were to seepage basins with the balance going directly to on-site streams (Table 5). Tributaries on the Savannah River Site feed five major on-site streams; all of which empty into the Savannah River (Figure 4). Streams were used for cooling water at reactors and separations facilities and returned to the Savannah River. Because of leaks in the heat exchangers, the streams were also conduits for varying quantities of radioactive materials into the aquatic and the terrestrial environment. Failed fuel elements in reactor storage basins and purge water from fuel element disassembly basins also resulted in the chronic release of radiocesium to streams on the Savannah River Site (Carlton et al., 1992).

Of the five major streams on the Savannah River Site (Figure 4), only Upper Three Runs Creek has not been impacted by radiocesium releases. Radiocesium releases to other on-site streams during the 1950 s totaled $62 \mathrm{Ci}(2.3 \mathrm{TBq})$ and cumulative historical releases of radiocesium were as follows:

- $\quad 77 \mathrm{Ci}(2.8 \mathrm{TBq})$ to Four Mile Creek;

- $\quad 24 \mathrm{Ci}(0.90) \mathrm{TBq}$ to Pen Branch;

- $284 \mathrm{Ci}(11 \mathrm{TBq})$ to Steel Creek; and

- $222 \mathrm{Ci}(8.2 \mathrm{TBq})$ to the Par Pond and Lower Three Runs system (Carlton et al., 1992).

Through 1989, the total amount of radiocesium released to streams at the Savannah River Site was approximately $608 \mathrm{Ci}(23 \mathrm{TBq}$ ) (Table 5 ). More than $99 \%$ of the radiocesium was ${ }^{137} \mathrm{Cs}$. Figure 6 shows the estimated annual discharge of radiocesium from the Savannah River Site, corrected for on-site retention. Through 1989, the off-site release of radiocesium was approximately $212 \mathrm{Ci}(7.8 \mathrm{TBq}$ ) (Carlton et al., 1992). Several short-term releases to onsite streams occurred in the late 1950s and early 1960s. In 1957, failure of an experimental fuel element resulted in the release of $46 \mathrm{Ci}(1.7 \mathrm{TBq})$ to Lower Three Runs Creek. Another failed fuel element in 1963 resulted in $84 \mathrm{Ci}(3.1 \mathrm{TBq})$ being released to Par Pond. Large releases of radiocesium (about 40 to $46 \mathrm{Ci}$ ) to Steel Creek occurred in 1964, 1967, and 1968 (Carlton et al., 1992). These events were accompanied by peak off-site releases in 1957 and 1963 (Figure 6).

\section{SITE SPECIFIC STUDIES OF RADIOCESIUM FATE AND TRANSPORT}

From the beginning of the U.S. nuclear weapons effort, environmental studies were a part of site operations at Oak Ridge, Hanford, and the Savannah River Site. These studies included measurements of environmental radioactive materials in air, soil, water, and biota along with research directed at a better understanding of the hazards posed by food-chain transport and by environmental migration of radiocesium through soils. One of the early lessons learned was that ${ }^{137} \mathrm{Cs}$ concentrations could be highly variable depending upon both the time and place of sampling. This spatial and temporal variability complicated data 
summarization, interpretation, and inter-site comparisons of radiocesium levels in the environment.

Environmental studies at U.S. nuclear weapons facilities during the 1950 s provide a record of early perspectives and findings on the importance of different pathways for radiocesium transport in the environment. These early studies indicate that researchers were interested in transport pathways that are commonly investigated in connection with environmental radioactivity (even up to the current day), including:

- uptake by native vegetation;

- effects of soil amendments on ${ }^{137} \mathrm{Cs}$ uptake by agricultural crops;

- food-chain transfer from plants to animals;

- potential for contaminant dispersal by wildlife; and

- effects of radiation exposure on plants and animals.

\section{Oak Ridge}

Environmental research during the 1950's, along with that which followed (e.g., Dahlman et al., 1975; Dahlman and Van Voris, 1976), consistently documented little plant uptake of radiocesium from contaminated soils at Oak Ridge. Plant-to-soil concentration ratios (i.e., $\mathrm{pCi} / \mathrm{g}$ plant $\div \mathrm{pCi} / \mathrm{g}$ soil) on the order of 0.05 were common. Studies of ${ }^{137} \mathrm{Cs}$ sorption by the local shales (Conasauga Group) during the late 1950's demonstrated that the low soil to plant transfer could be attributed to ${ }^{137} \mathrm{Cs}$ fixation by illitic clay minerals that are common in soils and sediments found on the Oak Ridge Reservation (Tamura and Jacobs, 1960).

Most early environmental studies at Oak Ridge were directed at learning more about the terrestrial ecology of the White Oak Lake bed. In October 1955, White Oak Lake was drained to provide more volume for mitigating the potential effects of a large release of radioactive materials to White Oak Creek and to reduce the likelihood of contaminated ducks (Oakes et al., 1982). There were also concerns about the structural integrity of White Oak Lake Dam which had been inundated by floodwaters in the fall of 1944 and later. The drainage of White Oak Lake in 1955 set the stage for erosion events in early 1956 that produced a dramatic increase in the release of radiocesium over White Oak Lake Dam (Figure 6). From 1956 to 1960 , the dry lake bed underwent rapid succession from a forb and sedge-rush community to a tree-shrub community (DeSelm and Shanks, 1967). Early studies showed no deleterious effects of radiation exposures on plants growing at this site (Plummer, 1960).

Radiocesium was soon recognized as a contaminant in biota inhabiting White Oak Lake bed. In the spring, 1957, studies were initiated to determine the uptake of radionuclides by agricultural crops (Auerbach and Crossley, 1958). Although there were differences between crops in the uptake of ${ }^{137} \mathrm{Cs}$, plant:soil concentration ratios (approximately 0.04 to 0.06 ) indicated little potential for bioaccumulation. Results from the agricultural experiments were in general agreement with studies of ${ }^{137} \mathrm{Cs}$ uptake by native vegetation on the Lake bed (Auerbach et al., 1959). Fertilizer experiments were found to have a dramatic effect on the 
uptake of ${ }^{137} \mathrm{Cs}$ by Sudan grass cultivated on the contaminated lake bed soil (Auerbach et al., 1961). Applications of superphosphate fertilizer at rates of approximately 1120,2240 , and $3360 \mathrm{~kg} /$ ha reduced ${ }^{137} \mathrm{Cs}$ uptake from lake bed soils by 37,68 , and $67 \%$, respectively. Thus, early radioecology studies indicated that soil amendments could potentially diminish plant uptake of radiocesium from soil.

Foodchain studies on White Oak Lake bed were begun in the summer of 1956 (Auerbach et al., 1958). Concentrations of ${ }^{137} \mathrm{Cs}$ in insects were almost as high as those in plant tissues upon which insects were feeding (Auerbach et al., 1959; Crossley and Pryor, 1960; Crossley and Howden, 1961) indicating no discrimination against radiocesium in insect foodchains. Radioecology studies at the site demonstrated that ${ }^{137} \mathrm{Cs}$ transport in the food chain was reduced at the point of soil to plant transfer while reduction in the foodchain transport of ${ }^{90} \mathrm{Sr}$ occurred principally at the point of plant-to-insect transfer (Crossley and Howden, 1961). Herbaceous and predaceous insects contained only $0.22 \mu \mathrm{Ci}(8140 \mathrm{~Bq}$ ) and $0.04 \mu \mathrm{Ci}$ $(1480 \mathrm{~Bq}){ }^{137} \mathrm{Cs} / \mathrm{ha}$, respectively, compared to a soil radiocesium inventory of $12 \mathrm{Ci}(0.44$ TB)/ha (Auerbach et al., 1960). Insect migration was shown to not be an important pathway for the redistribution of radiocesium from the contaminated lake bed (Crossley, 1963).

Research on small mammals and birds inhabiting the White Oak Lake bed was also initiated in the late 1950's to evaluate the uptake of fission products and the effect of long-term chronic effects of low level radiation on animal populations (Auerbach et al., 1958). Birds feeding close to the ground had the highest levels of radionuclide contamination due to the ingestion of contaminated soil (Willard, 1960). Willard (1960) estimated that the amount of ${ }^{137} \mathrm{Cs}$ in birds inhabiting the Lake bed was about $0.05 \mu \mathrm{Ci}(1740 \mathrm{~Bq}) / \mathrm{ha}$, and that bird migration as a potential pathway for radiocesium removal was negligible. Kaye and Dunaway (1962) estimated that from 1958 to 1960 , small mammal populations on the lake bed contained between approximately $0.03 \mu \mathrm{Ci}(1000 \mathrm{~Bq})$ and $0.05 \mu \mathrm{Ci}(1850 \mathrm{~Bq})^{137} \mathrm{Cs} / \mathrm{ha}$. Early studies indicated no discernable radiation effects on small mammals inhabiting White Oak Lake bed (Auerbach et al., 1963; Kaye and Dunaway, 1963).

\section{Hanford}

The Hanford Site contains numerous plant and animal species adapted to the region's semiarid environment. As noted by Johnson et al. (1994), at Hanford it is very difficult "to establish relationships between potential for contamination and radionuclide concentrations observed in biota beyond identifying contaminated areas of known access to biota." The contamination is isolated and relatively localized, even though it may spread beyond its intended waste boundary. Because of spatial and temporal variation, it is also difficult to develop parameters that may be useful for projecting the near- and long-term behavior of ${ }^{137} \mathrm{Cs}$ in the Hanford environment.

Waste disposal facilities at Hanford became a source of ${ }^{137} \mathrm{Cs}$ contamination in the environment, often spread by biota (Johnson et al., 1994). Some radionuclides were taken up by animals from the open disposal systems such as ditches and ponds that received 
liquid radioactive wastes (Emery and McShane, 1980). In other cases, deep-rooted plants, such as tumbleweed, transported subsurface ${ }^{137} \mathrm{Cs}$ to the surface. At Hanford, windblown tumbleweeds and other plants can transport radionuclides some distance before depositing contamination on the soil surface. Cataldo et al. (1978) studied plant:soil concentration ratios for radiocesium in cheatgrass and tumbleweed using five different Hanford area soils. Relatively little bioaccumulation was indicated for either type of vegetation (plant:soil concentration ratios ranged from 0.008 to 0.066 ) indicating that radiocesium is strongly sorbed to Hanford soils. At this site, radiocesium is readily bound by abundant micaceous and clay minerals (NAS, 1978).

Although there was relatively little soil to plant transfer of radiocesium at Hanford, the deep roots of some plants were capable of penetrating through uncontaminated surface soils into highly concentrated subsurface wastes in cribs and trenches and bringing radionuclides to the surface. For example, Klepper et al. (1979) studied the biota above a crib that was constructed in 1957 and used until 1966. It was covered with about $2 \mathrm{~m}$ of uncontaminated soil. Approximately $385 \mathrm{Ci}(14 \mathrm{TBq})$ of ${ }^{137} \mathrm{Cs}$ was in the crib when they conducted the study in 1975 . The ${ }^{137} \mathrm{Cs}$ was firmly attached to the soil particles and did not migrate downward in the soil column through percolation. Despite this, vegetation inhabiting the surface of the crib contained detectable amounts of ${ }^{137} \mathrm{Cs}$, some at a factor of 125 times greater than background. Pocket mice and harvester ants also contained elevated levels of ${ }^{137} \mathrm{Cs}$. In this case, plant roots and animals had penetrated the crib and brought contamination from buried waste to the ground surface.

O'Farrell and Gilbert (1975) described another example of a breached crib at Hanford. Between 1952 and 1958, Hanford's B-C Crib was used to dispose of waste that contained ${ }^{137} \mathrm{Cs}$ and other radionuclides. The ${ }^{137} \mathrm{Cs}$ was placed in trenches in a semi-solid surry (as ${ }^{137} \mathrm{CsCl}$ salts) and the trenches were backfilled. Sometime between 1958 and 1969, animals burrowed into some of the trenches and exposed the salt cake which, in turn, was consumed by other animals, especially jackrabbits. The ${ }^{137} \mathrm{CsCl}$ salts were actively sought by the animals because natural salt licks are rare at Hanford. Jackrabbits then spread the ${ }^{137} \mathrm{Cs}$ over several hectares via their feces. Predators also spread ${ }^{137} \mathrm{Cs}$ after consuming the jackrabbits.

\section{Savannah River Site}

Environmental monitoring on the Savannah River Site began in 1951 with baseline surveys in the Savannah River conducted by scientists from the Academy of Natural Sciences of Philadelphia (ANSP). Monitoring of radioactivity also began in 1951 (Figure 1) with the establishment of a site environmental monitoring program. More than 6000 environmental samples were analyzed between 1951 and 1953. The monitoring program was sensitive enough to detect radioactivity on vegetation from atmospheric nuclear testing at the Nevada Test Site in late 1951 (Bebbington, 1990). Researchers from the University of Georgia, Athens, also initiated studies of plants and animals at the Savannah River Site during the early 1950 s. 
Since the 1950s, monitoring locations at various facility out-falls have served to quantify the amount of radionuclides being transported by on-site streams to the Savannah River. Radiocesium released to Savannah River Site streams typically adsorbs to stream sediments near the point of release. Concentrations of cesium suspended in the water column are very low with sediments retaining a large portion of the environmental burden. Some of the radiocesium in on-site streams has been redistributed by physical transport of stream sediments. In 1966, a maximum of approximately $30 \mathrm{Ci}(1.1 \mathrm{TBq})$ of radiocesium was redistributed off-site in downstream sediments. By 1988 , the annual activity redistributed was about $5400 \mu \mathrm{Ci}(0.0002 \mathrm{TBq})$ (Carlton et al., 1992).

The Savannah River floodplain near Steel Creek contains ${ }^{137} \mathrm{Cs}$-contaminated sediments from years when large volumes of water flooded the river and transported radiocesium through the low-lying areas. The Steel Creek delta and swamp along the Savannah River floodplain (Figure 4) have been areas of special environmental studies on ${ }^{137} \mathrm{Cs}$ (e.g., Garten et al., 1975). Steel Creek travels approximately $3 \mathrm{~km}$ through the swamp before emptying into the Savannah River. From 1955 to 1973 , about $284 \mathrm{Ci}(10 \mathrm{TBq})$ of ${ }^{137} \mathrm{Cs}$ was released to Steel Creek, with less than $1 \%$ of that amount entering the creek after 1973 (Carlton et al., 1992).

Over the history of environmental releases at the Savannah River Site, more than $99 \%$ of the total off-site individual dose due to radiocesium is the result of exposures via the liquideffluent pathways. Liquid effluents of radiocesium also contributed about $75 \%$ to the total population dose (Carlton et al., 1992). The key factors influencing this result are: (1) the magnitude of cesium releases to on-site streams, and (2) the high affinity for cesium to bioaccumulate in the edible portion of fish (Harvey, 1964; Harvey, 1969; Shure and Gottschalk, 1975; Gladden, 1979; Whicker et al., 1989; Whicker et al., 1990). Bioconcentration factors for ${ }^{137} \mathrm{Cs}$ in fish at the Savannah River Site are typically on the order of 10000 and terrestrial plant:soil concentration ratios for are typically on the order of 1 to 10 (Cummins, 1994).

\section{DISCUSSION AND CONCLUSIONS}

Oak Ridge and Hanford were located during World War II with great consideration given to secrecy and engineering requirements (water, electricity, land, transportation, and available workforce) for the construction of facilities to build nuclear weapons. The wartime urgency to locate weapons facilities in remote and isolated places and the need to minimize the effect of climate on engineering and facility construction were the principal environmental considerations in facility siting. No considerations were given to possible environmental impacts. Radioecology and environmental impact assessment were largely undefined as scientific disciplines prior to the 1950s. Its high fission yield and ease of detection by gamma spectroscopy made radiocesium a prime candidate for early radioecological investigations. Although the environmental behavior of ${ }^{137} \mathrm{Cs}$ can be very different from that of other fission products and the transuranic elements, it was soon realized that 
radiocesium could be used to trace the transport of other radionuclides that had a high affinity for binding to primary soil particles (silts and clays).

The total amount of radiocesium released directly to the environment is approximately 640 $\mathrm{kCi}$ at Oak Ridge, $80 \mathrm{kCi}$ at Hanford, and $4.4 \mathrm{kCi}$ at the Savannah River Site. These are only rough estimates because, in many instances, waste disposal data are approximations. The estimates include radiocesium that was released through out-falls to aquatic ecosystems, tank leaks, and through surface land disposal in seepage basins, pits, and trenches. A "site retention index" can be calculated for radiocesium at Oak Ridge, Hanford, and the Savannah River Site by dividing estimated historical releases to the environment by estimates of cumulative off-site discharge $(703,65$, and $212 \mathrm{Ci}$, respectively). The site retention index is based on direct releases to the biosphere and does not consider radiocesium inventories that are contained in tank farms or shallow to deep geologic formations. The site retention index for radiocesium at Oak Ridge and Hanford (approximately 1000) is 50-fold greater than that at Savannah River Site (approximately 20 ).

From our current historical perspective, we can evaluate the reasons for site differences in the fate and transport of radiocesium. Radiocesium is strongly sorbed to soils at both Hanford (NAS, 1978) and Oak Ridge (Tamura and Jacobs, 1960). The greater environmental mobility at the Savannah River Site can be attributed to the relatively poor fixation of ${ }^{137} \mathrm{Cs}$ by kaolinitic clay minerals in sandy coastal plain soils (Brisbin et al., 1974; Garten et al., 1975; Cummins, 1994). Relatively higher site retention at Oak Ridge, despite much larger releases of ${ }^{137} \mathrm{Cs}$ directly to the environment, can be attributed to the strong fixation of radiocesium by illitic clay minerals (Tamura and Jacobs, 1960) in soils with a relatively high (>60\%) silt-clay content.' The high site retention index at Hanford results from the combination of a semi-arid climate and the strong binding of radiocesium to Hanford soils. This inter-site comparison supports an earlier conclusion by Dahlman et al. (1975) that ${ }^{137} \mathrm{Cs}$ fixation by soil coupled with geographic differences in soil type can be a major factor determining the long-term availability of ${ }^{137} \mathrm{Cs}$ in terrestrial and aquatic ecosystems.

\section{ACKNOWLEDGEMENTS}

We wish to thank Steve Stow and Dale Huff, both affiliated with Oak Ridge National Laboratory, for their helpful reviews of the draft manuscript. This manuscript is based on work performed at Oak Ridge National Laboratory, managed for the U. S. Department of Energy under contract DE-AC05-960R22464 with Lockheed Martin Energy Research Corporation. The work was also supported, in part, by the U. S. Nuclear Regulatory Commission through a grant to the National Council on Radiation Protection and Measurements, Bethesda, Maryland (Scientific Committee 64-23). We also thank other members of the Committee, F. Ward Whicker (Colorado State University), Kathryn A. Higley (Oregon State University), Tom G. Hinton (Savannah River Ecology Laboratory), and David J. Rowan (Colorado State University) for their contributions to the development of this manuscript. Publication No. $\$ \$ \$$, Environmental Sciences Division, Oak Ridge National Laboratory, Oak Ridge, Tennessee. 


\section{REFERENCES}

Anderson, J. D. 1974. Radioactive Liquid Wastes Discharged to Ground in the 200 Area During 1973 (ARH-2806). Atlantic Richfield Hanford Company, Richland, WA.

Auerbach, S. I., and D. A. Crossley, Jr. 1958. Strontium-90 and cesium-137 uptake by vegetation under natural conditions, pp. 494-499. IN Proceedings Second International Conference on Peaceful Uses of Atomic Energy, Vol. 18. Pergamon Press, London.

Auerbach, S. I., et al. 1958. Ecological Research, pp. 27-52. IN Health Physics Division Annual Progress Report, July 31, 1958 (ORNL-2590). Oak Ridge National Laboratory, Oak Ridge, Tennessee.

Auerbach, S. I., et al. 1959. Ecological Research, pp. 18-54. IN Health Physics Division Annual Progress Report, July 31, 1959 (ORNL-2806). Oak Ridge National Laboratory, Oak Ridge, Tennessee.

Auerbach, S. I., et al. 1960. Ecological Research, pp. 147-166. IN Health Physics Division Annual Progress Report, July 31, 1960 (ORNL-2994). Oak Ridge National Laboratory, Oak Ridge, Tennessee.

Auerbach, S. I., et al. 1961. White Oak Lake Bed Studies, pp. 81-105. IN Health Physics Division Annual Progress Report, July 31, 1961 (ORNL-3189). Oak Ridge National Laboratory, Oak Ridge, Tennessee.

Auerbach, S. I., et al. 1963. Radiation Ecology, pp. 81-115. IN Health Physics Division Annual Progress Report, June 30, 1963 (ORNL-3492). Oak Ridge National Laboratory, Oak Ridge, Tennessee.

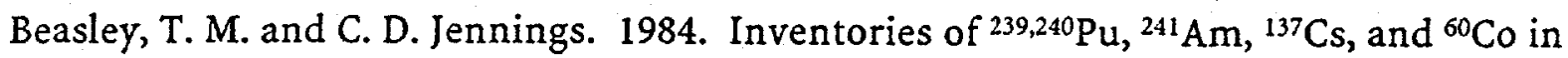
Columbia River sediments from Hanford to the Columbia River Estuary. Environmental Science and Technology 18: 207-212.

Bebbington, W. P. 1990. History of Du Pont at the Savannah River Plant. E. I. Du Pont de Nemours and Company, Wilmington, Delaware.

Braustein, H. M., W. A. Alexander, H. M. Hubbard, T. W. Oakes, W. F. Ohnesorge. 1984. An Investigation of the Concentration, Distribution, and Inventory of Radionuclides in Sediment of Process Waste System Basin 3524 (ORNL/TM-8682). Oak Ridge National Laboratory, Oak Ridge, Tennessee. 
Brisbin, I. L., Jr., R. J. Beyers, R. W. Dapson, R. A. Geiger, J. B. Gentry, J. W. Gibbons, M. H. Smith, and S. K. Woods. 1974. Patterns of radiocesium in the sediments of a stream channel contaminated with production reactor effluents. Health Physics 27: 19-27.

Carlton, W. H., L. R. Bauer, A. G. Evans, L. A. Geary, C. E. Murphy, Jr., J. E. Pinder, and R. N. Strom. 1992. Cesium in the Savannah River Site Environment (WSRC-RP-92-250). Westinghouse Savannah River Company, Savannah River Site, Aiken, South Carolina.

Cataldo, D. A., R. C. Routson, D. Paine, and T. R. Garland. 1978. Relationships Between Properties of Hanford Area Soils and the Availability of ${ }^{134} \mathrm{Cs}$ and ${ }^{85} \mathrm{Sr}$ for Uptake by Cheatgrass and Trumbleweed (PNL-2496). Pacific Northwest Laboratory, Richland, Washington.

Clapp, R. B., J. A. Watts, and M. A. S. Guth (eds.). 1995. Third Annual Environmental Restoration Monitoring and Assessment Report for FY 1994, Oak Ridge National Laboratory, Oak Ridge, Tennessee (ORNL/ER-250). Oak Ridge National Laboratory, Oak Ridge, Tennessee.

Clapp, R. B., Y. S. Bao, T. D. Moore, A. L. Brenkert, S. T. Purucker, D. K. Reece, and B. B. Burgoa. 1996. Waste Area Grouping 2 Phase I Remedial Investigation: Sediment and Cesium-137 Transport Modeling Report (ORNL/ER-367). Oak Ridge National Laboratory, Oak Ridge, Tennessee.

Coobs, J. H., and J. R. Gissel. 1986. History of Disposal of Radioactive Wastes into the Ground at Oak Ridge National Laboratory (ORNL/TM-10269). Oak Ridge National Laboratory, Oak Ridge, Tennessee.

Crossley, D. A., Jr., and M. E. Pryor. 1960. The uptake and elimination of cesium-137 by a grasshopper - Romalea microptera. Health Physics 4: 16-20.

Crossley, D. A., Jr., and H. F. Howden. 1961. Insect-vegetation relationships in an area contaminated by radioactive wastes. Ecology 42: 302-317.

Crossley, D. A., Jr. 1963. Movement and accumulation of radiostrontium and radiocesium in insects, pp. 103-105. In (V. Schultz, and A. W. Klement, Jr., eds.) Proceedings First National Symposium on Radioecology. Reinhold Publishing Company, New York, and AIBS, Washington, D. C.

Cummins, C. L. 1994. Radiological Bioconcentration Factors for Aquatic, Terrestrial, and Wetland Ecosystems at the Savannah River Site (WSRC-TR-94-0391).

Cushing, C. E. (ed). 1992. Hanford Site National Environmental Policy Act (NEPA) Characterization (PNL-6415 Rev 5). Pacific Northwest Laboratory, Richland, Washington. 
Dahlman, R. C., C. W. Francis, and T. Tamura. 1975. Radiocesium cycling in vegetation and soil, pp. 462-481. IN (F. G. Howell, J. B. Gentry, and M. H. Smith, eds.) Mineral Cycling in Southeastern Ecosystems (CONF-740513). National Technical Information Service, Springfield, Virginia.

Dahlman, R. C., and P. Van Voris. 1976. Cycling of ${ }^{137} \mathrm{Cs}$ in soil and vegetation of a flood plain 30 years after initial contamination, pp. 291-298. IN (C. E. Cushing, Jr., ed.) Radioecology and Energy Resources. Dowden, Hutchinson, and Ross, Inc., Stroudsburg, Pennsylvania.

Daubenmire, R. 1970. Steep Vegetation of Washington. Technical Bulletin 62, Experimental Station, Washington State University, Pullman, Washington.

DeSelm, H. R., and R. E. Shanks. 1967. Vegetation and floristic changes on a portion of White Oak Lake bed. Ecology 48: 419-425.

DOE (US Department of Energy). 1995. Closing of the Circle on the Splitting of the Atom: The Environmental Legacy of Nuclear Weapons Production in the United States and What the Department of Energy is Doing About It. Office of Environmental Management, Washington, DC.

DOE (US Department of Energy). 1997. Linking legacies: Connecting the Cold War Nuclear Weapons Production Processes to Their Environmental Consequences (DOE/EM-0319). Office of Environmental Management, Washington, D.C.

Emery, R. M., and M. C. McShane. 1980. Nuclear waste ponds and streams on the Hanford Site: An ecological search for radiation effects." Health Physics 38: 787-809.

Francis, C. W., and O. M. Sealand. 1987. Concentrations of Radionuclides in ORNL Wastepond Sediments and their Leaching Characteristics (ORNL/RAP/LTR-87/70). Oak Ridge National Laboratory, Oak Ridge, Tennessee.

Garten, C. T., Jr., J. B. Gentry, J. E. Pinder, III, R. R. Sharitz, and M. H. Smith. 1975. Radiocesium dynamics in a contaminated floodplain ecosystem in the southeastern United States, pp. 331-347. IN Impacts of Nuclear Releases into the Aquatic Environment. International Atomic Energy Agency, Vienna.

Gephart, R. E., R. C. Arnett, R. G. Baca, L. S. Leonhart, and F. A. Spane, Jr. 1979. Hydrologic Studies Within the Columbia Plateau, Washington: An Integration of Current Knowledge (RHO-BWI-ST-5). Rockwell Hanford Operations, Richland, Washington.

Gladden, J. B. 1979. Radiocesium Exchange Among Components of a Coastal Plain Bottomland Stream Ecosystem. Ph.D. Dissertation (abstract). Emory University, Atlanta, Georgia. 
Graham, M. J., M. D. Hall, S. R. Strait, W. R. Brown. 1981. Hydrology of the Separations Area (RHO-ST-42). Rockwell Hanford Operations, Richland, Washington.

Hajek, B. F. 1966. Soil Survey: Hanford Project in Benton County, Washington (BNWL-243). Pacific Northwest Laboratory, Richland, Washington.

Hamilton, L. V., D. C. West, L. W. McMahon, L. G. Shipe, J. G. Rogers, and W. S. Koncinski. 1996. Oak Ridge Reservation Annual Site Environmental Report for 1995 (ES/ESH/69). Oak Ridge National Laboratory, Oak Ridge Y-12 Plant, and the Oak Ridge K-25 Site, Oak Ridge, Tennessee.

Hamilton, L. V., S. D. Thompson, H. M. Braustein, L. W. McMahon, L. G. Shipe, J. G. Rogers, W. S. Koncinski, and J. H. Campbell. 1997. Oak Ridge Reservation Annual Site Environmental Report for 1996 (ES/ESH-73). Oak Ridge National Laboratory, Oak Ridge Y12 Plant, and the Oak Ridge K-25 Site, Oak Ridge, Tennessee.

Harvey, R. S. 1964. Uptake of radionuclides by freshwater algae and fish. Health Physics 10: 243-247.

Harvey, R. S. 1969. Uptake and loss of radionuclides by the freshwater clam Lampsilis radiata (Gmel.). Health Physics 17: 149-154.

Hatcher, R. D., Jr., P. J. Lemiszki, R. B. Dreier, R. H. Ketelle, R. R. Lee, D. A. Leitzke, W. M. McMaster, J. L. Foreman, and S. Y. Lee. 1992. Status Report on the Geology of the Oak Ridge Reservation (ORNL/TM-12074). Oak Ridge National Laboratory, Oak Ridge, Tennessee.

Heeb, C. M. and D. J. Bates. 1994. Radionuclide Releases to the Columbia River from the Hanford Operations, 1944-1971 (PNWD-2223-HEDR-Vol. 1). Pacific Northwest Laboratory, Richland, Washington.

Heirgesell, B. Savannah River Site geologist. Personal Communication. June 1999.

Huff, D. D., G. R. Moline, L. E. Toran, A. J. Stewart, R. B. Clapp, and C. T. Rightmire. 1998. Environmental Sciences Division Groundwater Program Office Report for Fiscal Years 19951997 (ORNL/GWPO-027). Oak Ridge National Laboratory, Oak Ridge, Tennessee.

Jago, W. K., R. S. Loffman, and C. A. Motley. 1997. 7. Groundwater, pp. 7-1 to 7-54. IN (Hamilton et al., eds.) Oak Ridge Reservation Annual Site Environmental Report for 1996 (ES/ESH-73). Oak Ridge National Laboratory, Oak Ridge Y-12 Plant, and the Oak Ridge K-25 Site, Oak Ridge, Tennessee. 
Johnson, A. R., B. M. Markes, J. W. Schmidt, A. N. Shah, S. G. Weiss, and K. J. Wilson. 1994. Historical Records of Radioactive Contamination in Biota at the 200 Areas of the Hanford Site (WHC-MR-0412, Rev 0). Westinghouse Hanford Company, Richland, Washington.

Kaye, S. V., and P. B. Dunaway. 1962. Bioaccumulation of radioactive isotopes by herbivorous small mammals. Health Physics 7: 205-217.

Kaye, S. V., and P. B. Dunaway. 1963. Estimation of dose rate and equilibrium state from bioaccumulation of radionuclides by mammals, pp. 107-111. IN (V. Schultz and A. W. Klement, Jr., eds.) Proceedings First National Symposium on Radioecology. Reinhold Publishing Company, New York, and AIBS, Washington, D. C.

Klepper, E. L., L. E. Rogers, J. D. Hedlund, and R. G. Schreckhise. 1979. Radioactivity Associated with Biota and Soil of the 216-A-24 Crib (PNL-1948). Pacific Northwest Laboratory, Richland, Washington.

Loar, J. M. (ed.) 1988. Second Annual Report on the ORNL Biological Monitoring and Abatement Program. Oak Ridge National Laboratory, Oak Ridge, Tennessee.

Loar, J. M. (ed.) 1989. Third Annual Report on the ORNL Biological Monitoring and Abatement Program. Oak Ridge National Laboratory, Oak Ridge, Tennessee.

Lomenick, T. F., and D. A. Gardiner. 1965. The occurrence and retention of radionuclides in the sediments of White Oak Lake. Health Physics 11: 567-577.

Lomenick, T. F., D. G. Jacobs, and E. G. Struxness. 1967. The behavior of strontium-90 and cesium-137 in seepage pits at ORNL. Health Physics 13: 897-905.

Myrick, T. E., and S. H. Stow. 1987. Remedial action plan for ORNL hydrofracture operations (ORNL/RAP-9). Oak Ridge National Laboratory, Oak Ridge, Tennessee.

Napier, B. A. 1992. Determination of Radionuclides and Pathways Contributing to Cumulative Dose (BN-SA-3673 HEDR). Battelle, Pacific Northwest Laboratories, Richland, Washington.

NAS (National Academy of Sciences). 1978. Radioactive Wastes at the Hanford Reservation: A Technical Review. National Academy of Sciences, Washington, DC.

Oakes, T. W., B. A. Kelly, W. F. Ohnesorge, J. S. Eldridge, J. C. Bird, K. E. Swank, and F. S. Tsakeres. 1982. Technical Background Information for the Environmental and Safety Report, Volume 4: White Oak Lake and Dam (ORNL-5681). Oak Ridge National Laboratory, Oak Ridge, Tennessee. 
O'Farrell, T. P. and R. O. Gilbert. 1975. Transport of radioactive materials by jackrabbits on the Hanford Reservation. Health Physics, 29: 9-15.

Pinder J.E., K. K. Guy, T. E. Rea, and D. J. Karapatakis. 1998. Development of a 1997 Habitat Map for the Savannah River Site: Final Report to Westinghouse Savannah River Company. Savannah River Ecology Laboratory, Aiken, South Carolina.

Plummer, G. L. 1960. Biometric Analysis of a Growth Response of Two Plant Species in a Radioactive Waste Area (ORNL-2903). Oak Ridge National Laboratory, Oak Ridge, TN.

Shure, D. J., and M. R. Gottschalk. 1975. Cesium-137 dynamics within a reactor effluent stream in South Carolina, pp. 234-241. IN (C. E. Cushing, Jr., ed.) Radioecology and Energy Resources, Proceedings of the Fourth National Symposium on Radioecology. The Ecological Society of America, Special Publication No. 1. Washington, DC.

Solomon, D. K., G. K. Moore, L. E. Toran, R. B. Dreier, and W. M. McMaster. 1992. A Hydrologic Framework for the Oak Ridge Reservation (ORNL/TM-12026). Oak Ridge National Laboratory, Oak Ridge, Tennessee.

Spalding, B. P. 1987. Environmental Data Package for the ORNL Seepage Pits and Trenches Waste Area Grouping (ORNL/RAP-10). Oak Ridge National Laboratory, Oak Ridge, Tennessee.

Stow, S. H., and R. J. Serne. 1999. Release of radionuclides to soils and sediments in the United States in the 1950's. Proceedings HISAP ' 99.

Tamura, T., and D. G. Jacobs. 1960. Structural implications in cesium sorption. Health Physics 2: 391-398.

Tamura, T., O. M. Sealand, and J. O. Duguid. 1977. Preliminary Inventory of ${ }^{239,240} \mathrm{Pu},{ }^{90} \mathrm{Sr}$, and ${ }^{137} \mathrm{Cs}$ in Waste Pond No. 2 (3513) (ORNL/TM-5802). Oak Ridge National Laboratory, Oak Ridge, Tennessee.

TVA (Tennessee Valley Authority). 1972. A continuous daily streamflow model. Research Paper No. 8. Tennessee Valley Authority, Knoxville, Tennessee.

Uziel, M. S., P. F. Tiner, and J. K. Williams. 1991. Surface Radiological Investigations of Trench 6 and Low Level Waste Line Leak Site 7.4b at the Oak Ridge National Laboratory, Oak Ridge, Tennessee (ORNL/ER-37). Oak Ridge National Laboratory, Oak Ridge, Tennessee.

Wells, D. 1994. Radioactivity in Columbia River Sediments and Their Health Effects. Environmental Radiation Program Special Report, Washington State Department of Health, Olympia, Washington. 
Whicker, F. W., J. E. Pinder, J. W. Bowling, J. J. Alberts, and I. L. Brisbin. 1989. Distribution of Cs-137, Sr-90, Pu-238, Pu-239, Am-241, and Cm-244 in Pond B, Savannah River Site (SREL35, UC-66e). Savannah River Ecology Laboratory, Aiken, South Carolina.

Whicker, F. W., J. E. Pinder, III, J. W. Bowling, J. J. Alberts, and I. L. Brisbin. 1990. Distribution of long-lived radionuclides in an abandoned reactor cooling reservoir. Ecological Monographs 60: 471-496.

Willard, W. K. 1960. Avian uptake of fission products from an area contaminated by lowlevel atomic wastes. Science 132: 148-150.

Williams, J. K., J. A. Roberts, and M. S. Uziel. 1988. Radiological Investigations of Areas Near Trench 7 and Including LLW Line Leak Sites (ORNL/RAP/LTR-87/46). Oak Ridge National Laboratory, Oak Ridge, Tennessee.

WSRC (Westinghouse Savannah River Company). 1991. Radioactive Releases at the Savannah River Site, 1954-1989 (WSRC-RP-91-684). Westinghouse Savannah River Company, Aiken, South Carolina.

WSRC (Westinghouse Savannah River Company). 1997. Savannah River Site Environmental Report for 1996 (WSRC-TR-97-0171). Westinghouse Savannah River Company, Aiken, South Carolina. 
Table 1. Comparison of the major roles of the Oak Ridge Reservation, Hanford Site, and Savannah River Site in the production of U.S. nuclear weapons and some of the nuclear materials handled at each facility in the 1940s and 1950s (DOE, 1997).

\begin{tabular}{llll}
\hline Process & Oak Ridge & Hanford & Savannah River \\
\hline Uranium refining & $\begin{array}{l}\text { Weapons parts } \\
\text { and reactor fuel }\end{array}$ & \\
& U and Li & & Heavy water \\
Isotope separation & $\mathrm{Li}$ & $\mathrm{U}$ & $\mathrm{U}, \mathrm{HEU}, \mathrm{Li}$ \\
Fuel and target fabrication & & 9 & 5 \\
Reactor operations & & $\mathrm{Pu}, \mathrm{U}$ & $\mathrm{Pu}, \mathrm{U},{ }^{3} \mathrm{H}$ \\
Chemical separations & & $\mathrm{Pu}$ & ${ }^{3} \mathrm{H}$ \\
Weapons component fabrication & $\mathrm{U}, \mathrm{HEU}, \mathrm{Li}$ & ${ }^{2}$ & \\
\hline
\end{tabular}

$* \mathrm{HEU}=$ highly enriched uranium. 
Table 2. Comparison of annual climate data at Oak Ridge, Hanford, and Savannah River. Temperature and precipitation data are from 30-year climate normals. PET is potential evapotranspiration.

\begin{tabular}{|c|c|c|c|c|}
\hline Location & Climate & $\begin{array}{r}\text { Potential } \\
\text { Evapotran- } \\
\text { spiration } \\
(\mathrm{cm})\end{array}$ & $\begin{array}{r}\text { Annual } \\
\text { Temperature } \\
\left({ }^{\circ} \mathrm{C}\right)\end{array}$ & $\begin{array}{r}\text { Annual } \\
\text { Precipitation } \\
(\mathrm{cm})\end{array}$ \\
\hline Oak Ridge, TN & $\begin{array}{l}\text { Humid- } \\
\text { temperate }\end{array}$ & $61-91$ & 13.7 & 137 \\
\hline Hanford, WA & Cool-arid & $61-91$ & 9.9 & 20 \\
\hline Savannah River Site, SC & Subtropical & $91-122$ & 17.3 & 113 \\
\hline
\end{tabular}


Table 3. Radiocesium inventories in various aquatic impoundments at Oak Ridge.

\begin{tabular}{lll}
\hline Site & $\begin{array}{c}\text { Estimated Range } \\
137 \mathrm{Cs}(\mathrm{Ci})\end{array}$ & References \\
\hline Pond 3513 and 3524 & 135 to 303 & $\begin{array}{l}\text { Tamura et al. (1977), Braunstein et } \\
\text { al. (1984), Francis and Sealand (1987) }\end{array}$ \\
Intermediate Pond on WOC & 105 to 800 & $\begin{array}{l}\text { Dahlman and Van Voris (1976), Clapp } \\
\text { et al. (1995), Clapp et al. (1996) }\end{array}$ \\
White Oak Lake & 324 to 703 & $\begin{array}{l}\text { Lomenick et al. (1967), Oakes et al. } \\
\text { (1982), Loar et al. (1988), Loar et al. } \\
\text { (1989), Clapp et al. (1995), } \\
\text { Clapp et al. (1996) }\end{array}$ \\
\hline
\end{tabular}


Table 4. Estimated past discharge of radiocesium $\left({ }^{137} \mathrm{Cs}\right)$ to waste disposal pits and trenches at Oak Ridge.

Site

Notes

${ }^{137} \mathrm{Cs}(\mathrm{Ci})$

References

Pit 1

Pits 2, 3, 4

Trench 5

Trench 6

Trench 7

\section{1}

2

3

4

5
$--$

201000

205400

660

232400
Coobs and Gissel (1986)

Coobs and Gissel (1986)

Spalding 1987

Uziel et al. (1991)

Williams et al. (1988)

Notes to Table 4:

[1] Pit 1 was constructed in 1951 for the disposal of concentrated liquid radioactive wastes received about approximately $400 \mathrm{Ci}(15 \mathrm{TBq})$ of radioactivity.

[2] Pits 2, 3, and 4 were operatëd between 1952 and 1962 and collectively were used to dispose of approximately $91000 \mathrm{~m}^{3}$ of liquid radioactive waste.

[3] Trench 5 was constructed in 1960 and was used to dispose of approximately $36000 \mathrm{~m}^{3}$ of liquid radioactive waste.

[4] Built in 1961, Trench 6 received a total of approximately $490 \mathrm{~m}^{3}$ of liquid radioactive wastes.

[5] Between 1962 and 1966, Trench 7 received approximately $32000 \mathrm{~m}^{3}$ of liquid radioactive wastes. 
Table 5. Estimated past discharge of radiocesium $\left({ }^{137} \mathrm{Cs}\right)$ to streams and seepage basins at the Savannah River Site (Carlton et al., 1992).

\section{Radiocesium (Ci)}

Disposal to

Reactors Separation Facilities Totals

Streams

Seepage Basins

564

938

44

414

608

Tank Farms

Solid Waste Disposal Facility

$-$

260000000

1960

$-$

$--$

260000000

1809 


\section{LIST OF FIGURES}

Figure 1. Early history of events at the three major U.S. weapons production facilities (Oak Ridge Reservation, Hanford Site, and Savannah River Site). Events in italics show significant socio-political events that contributed to the Cold War of the 1950s.

Figure 2. Map of the Oak Ridge Reservation.

Figure 3. Map of the Hanford Site.

Figure 4. Map of the Savannah River Site.

Figure 5. Mean monthly temperature and precipitation data Oak Ridge, Hanford, and Savannah River based on 30-year climate normals.

Figure 6. Estimated annual off-site discharge of radiocesium from Oak Ridge National Laboratory and the Savannah River Site. The discharge point at Oak Ridge is the White Oak Lake Dam. Discharge data for the Savannah River Site are from Carlton et al. (1992) and are corrected for on-site retention in ponds and streams. 


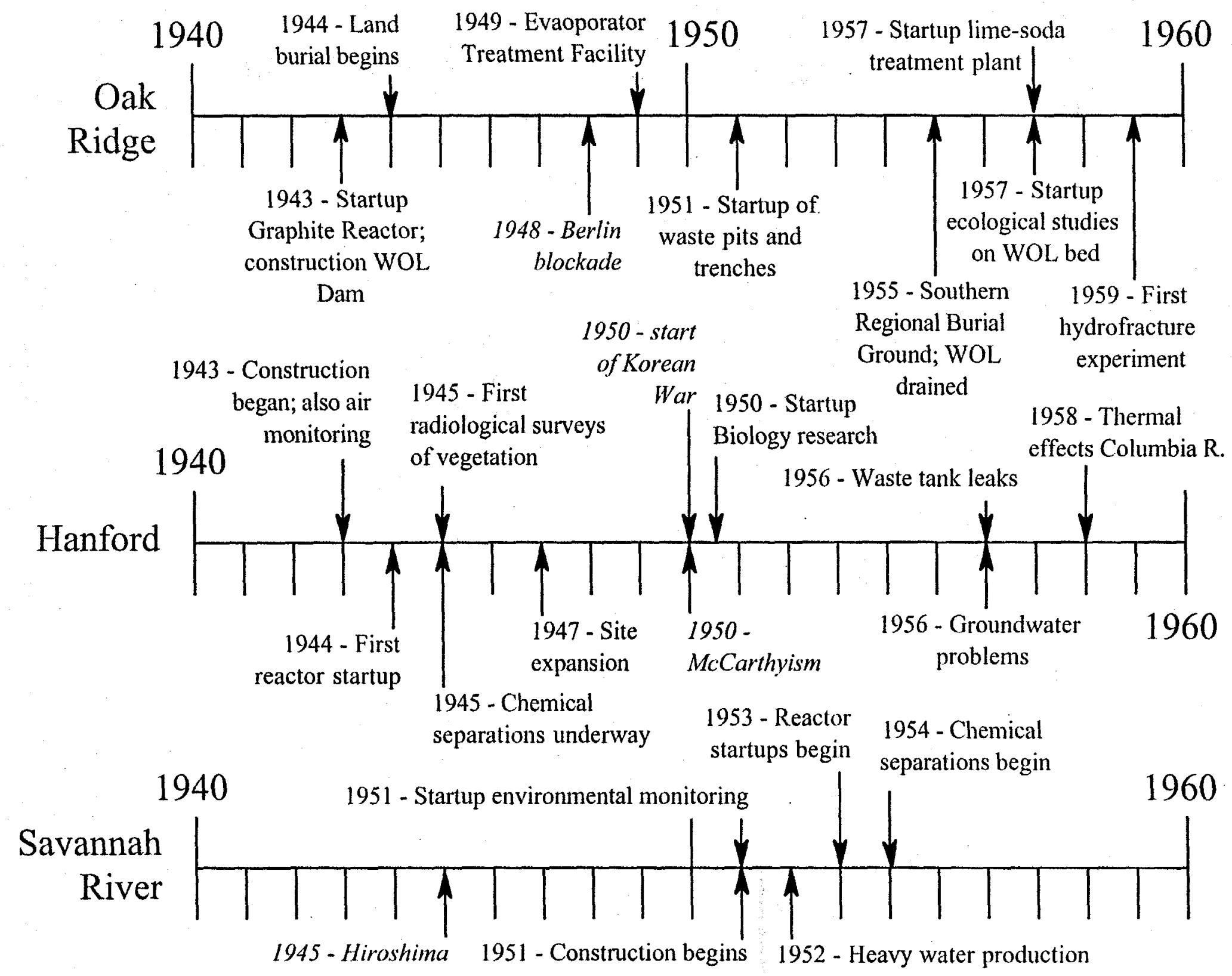


Figure 2.

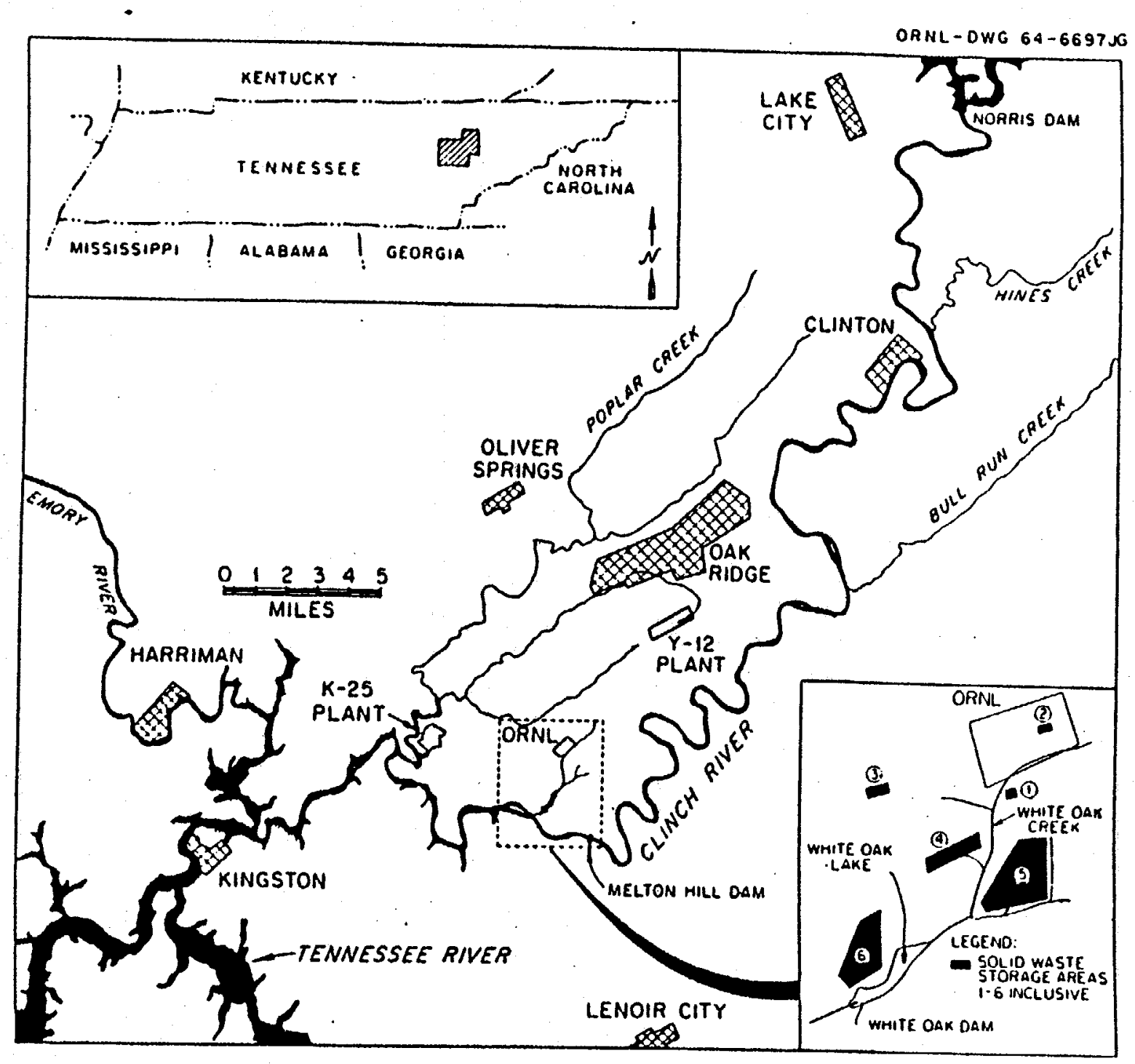




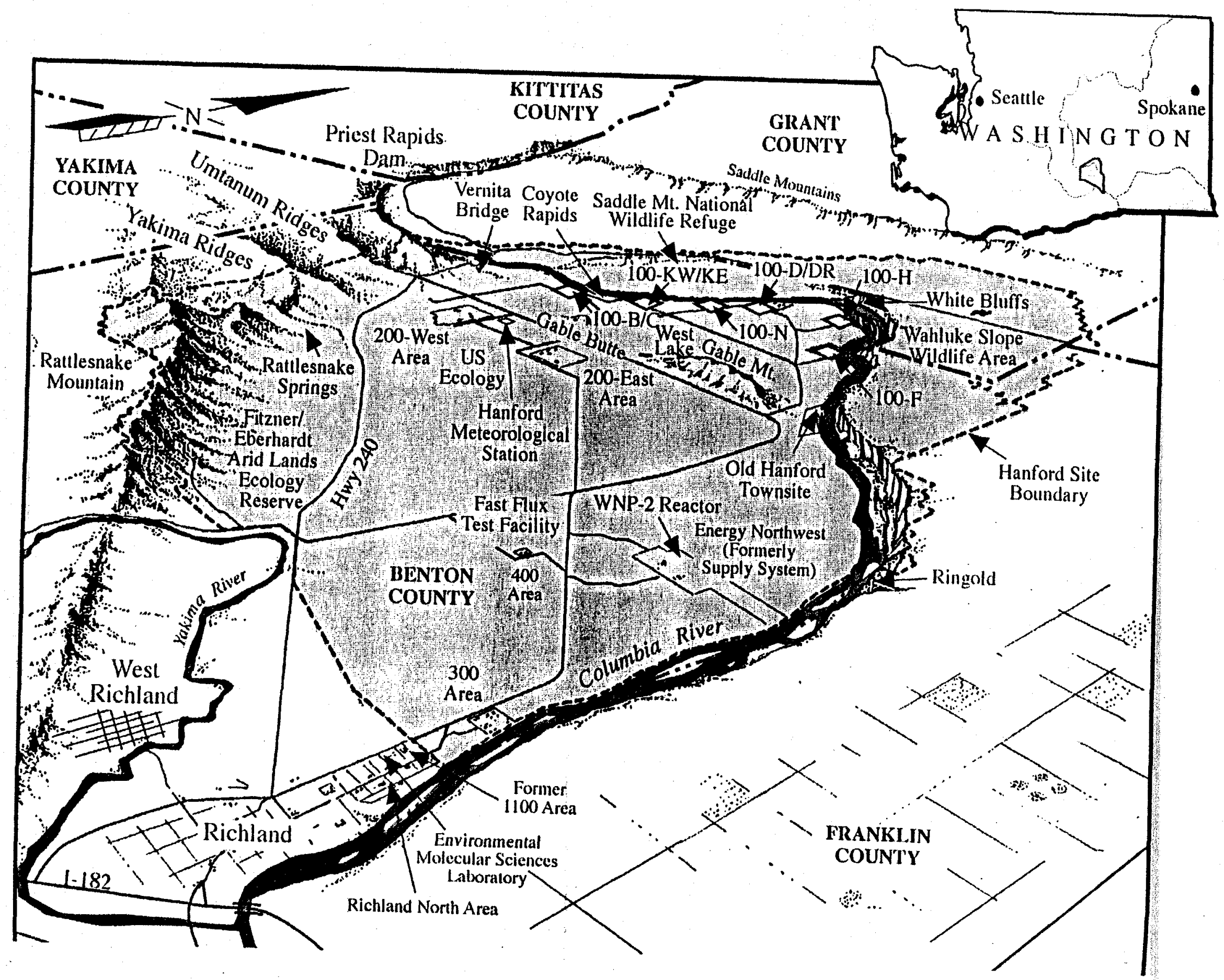




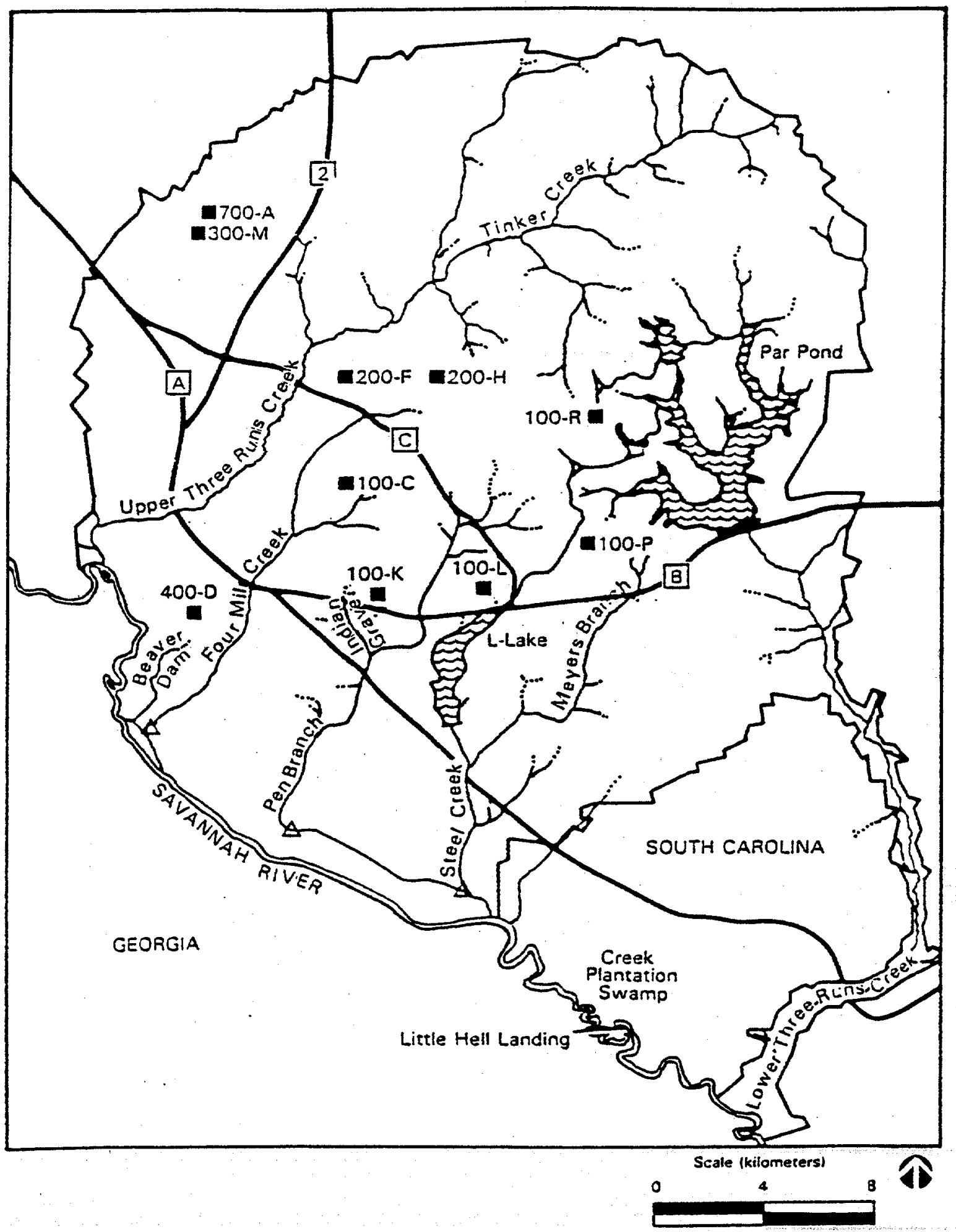



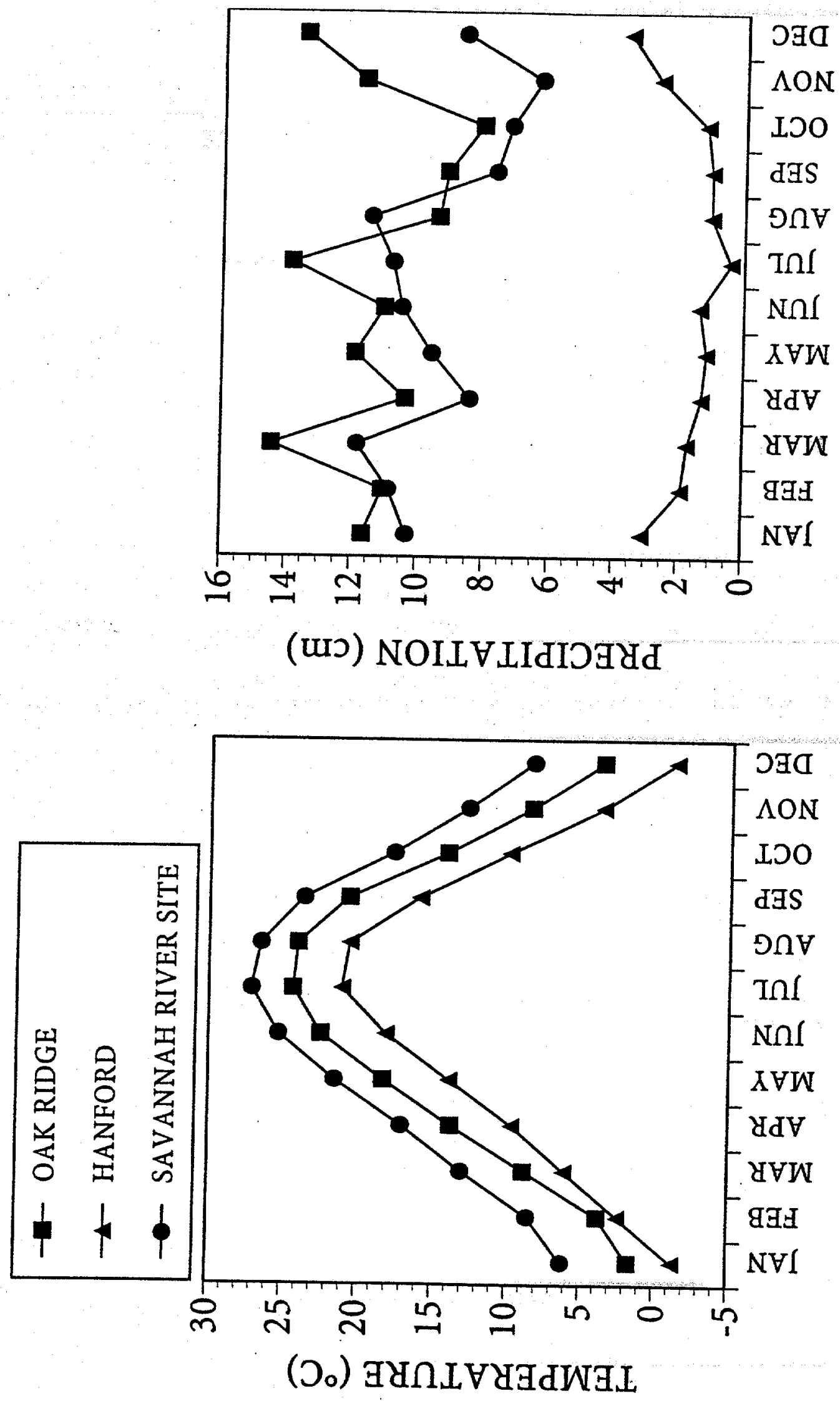


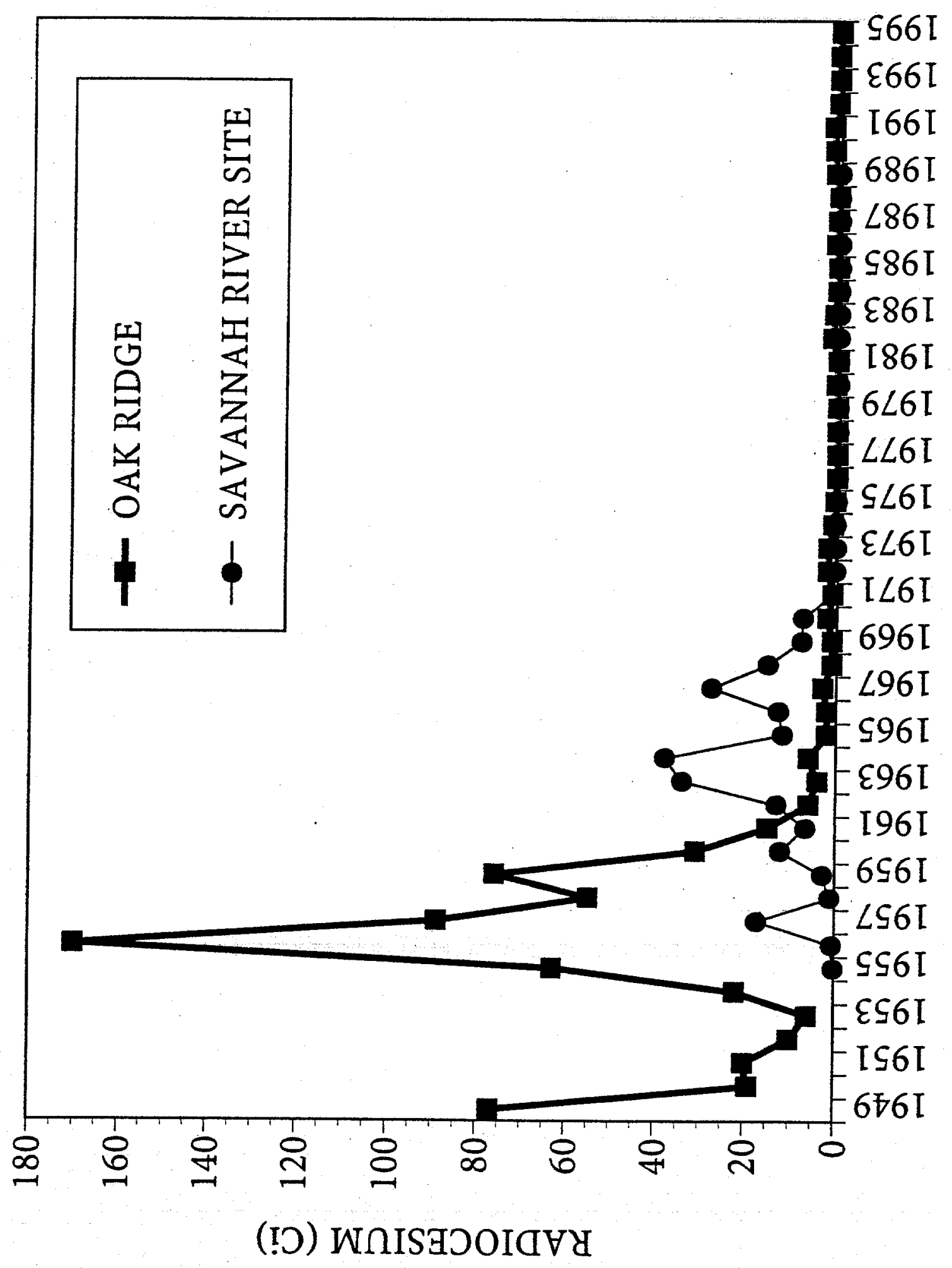




\title{
RADIOCESIUM DISCHARGES AND SUBSEQUENT ENVIRONMENTAL TRANSPORT AT THE MAJOR U.S. WEAPONS PRODUCTION FACILITIES
}

\author{
C. T. Garten, Jr. \\ Environmental Sciences Division, Oak Ridge National \\ Laboratory, Oak Ridge, Tennessee \\ D. M. Hamby \\ School of Public Health, University of Michigan, Ann Arbor, \\ Michigan
}

\author{
R. G. Schreckhise \\ Washington State University - Tricities Campus, Richland, \\ Washington
}




\section{REASONS FOR AN HISTORICAL OVERVIEW OF RADIOCESIUM}

One of the more prevalent radionuclides released as a result of historical atomic projects in the United States and the former Soviet Union

Discharges during the 1950s account for a large fraction of historical releases from U.S. weapons facilities

- Radiocesium releases during the early years of weapons production provided an opportunity for multidisciplinary studies of environmental behavior and transport

Retrospective evaluation of the reasons for differences in radiocesium fate and transport at three facilities that played major roles in the production of U.S. nuclear weapons 


\section{COMPARISON OF THE MAJOR ROLES OF OAK RIDGE, HANFORD, AND SAVANNAH RIVER SITE IN THE U.S. NUCLEAR WEAPONS PRODUCTION PROCESS (SOURCE: DOE 1997)}

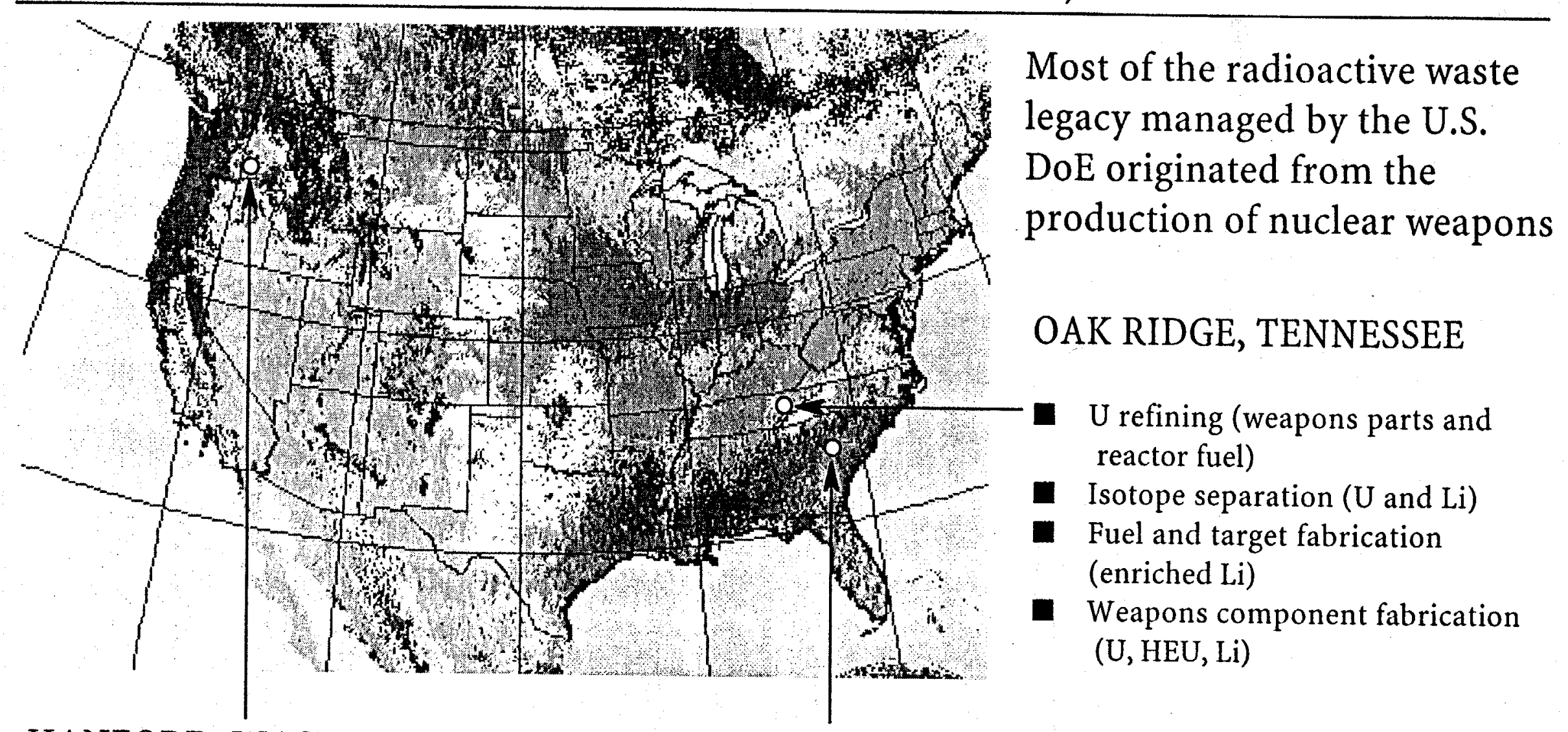

HANFORD, WASHINGTON

- U fuel and target fabrication

- 9 production reactors

- U recycling (chemical separations)

- Pu finishing plant (weapons component fabrication)

\section{SAVANNAH RIVER SITE, SOUTH CAROLINA}

- Heavy water (isotope separation)

- Fuel and target fabrication (HEU, U, enriched Li)

- 5 production reactors

- Chemical separations ( $\mathrm{Pu}, \mathrm{U}$, tritium)

- Weapons component fabrication (tritium recycling) 


\section{OAK RIDGE SETTING}

Map of Oak Ridge and Surrounding Vicinity

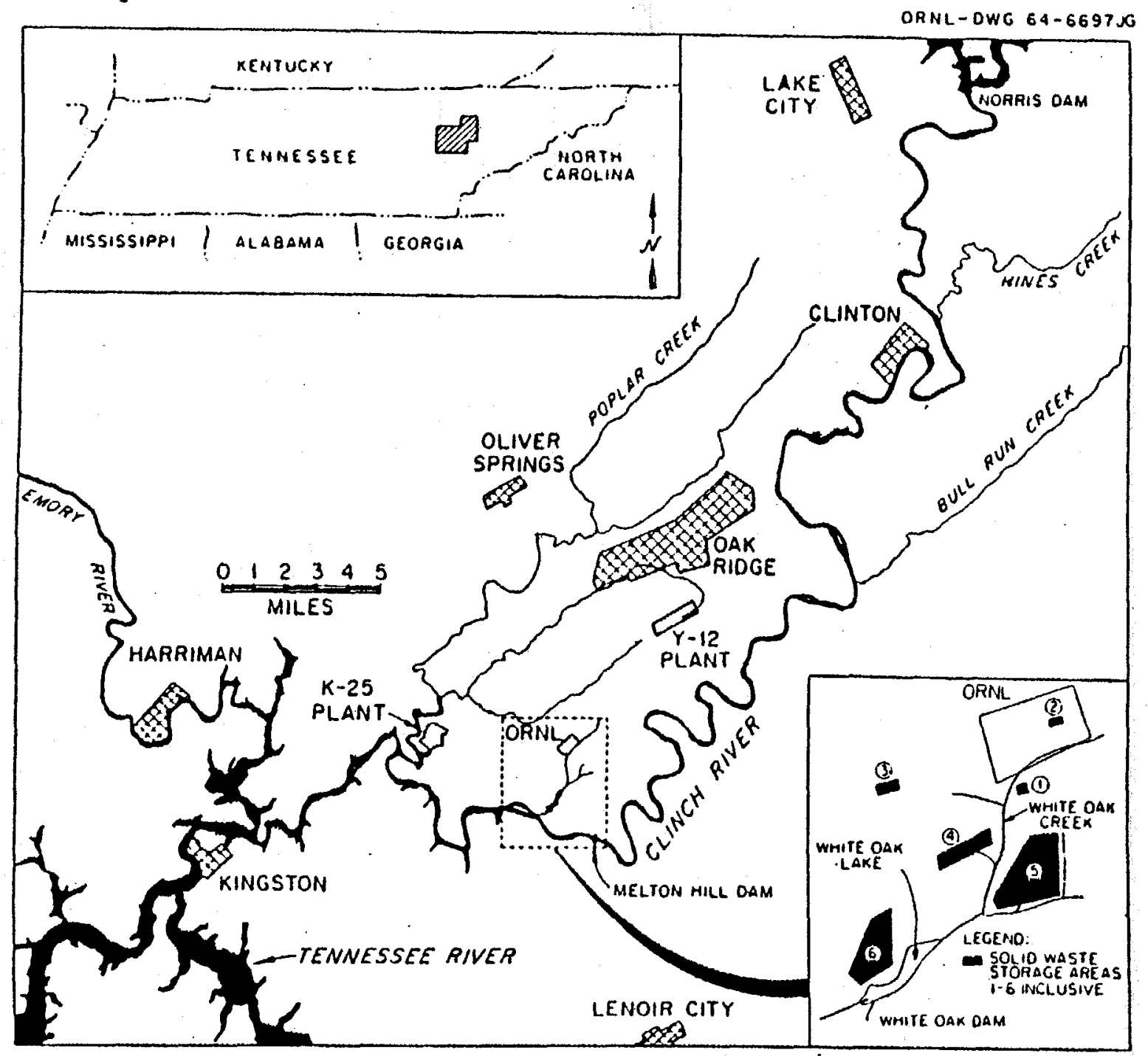

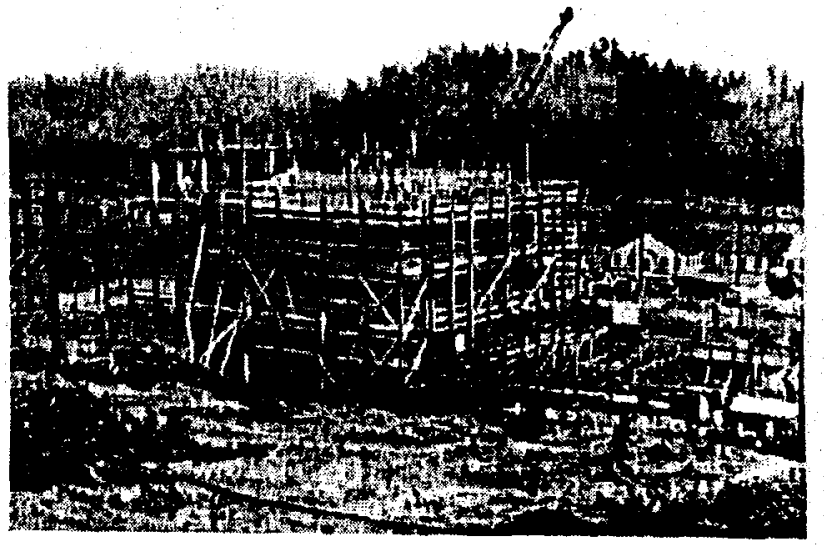

Construction of Graphite Reactor (1943)

- Area of the Oak Ridge Reservation is $\approx 140$ square $\mathrm{km}$

- Land use prior to government acquisition was agriculture and forestry

- Dominant vegetation is temperate deciduous forest

- Clinch River is a major hydrologic feature

- Major site of radiocesium contamination is White Oak Creek watershed 


\section{HANFORD SETTING}

Map of Hanford and Surrounding Vicinity

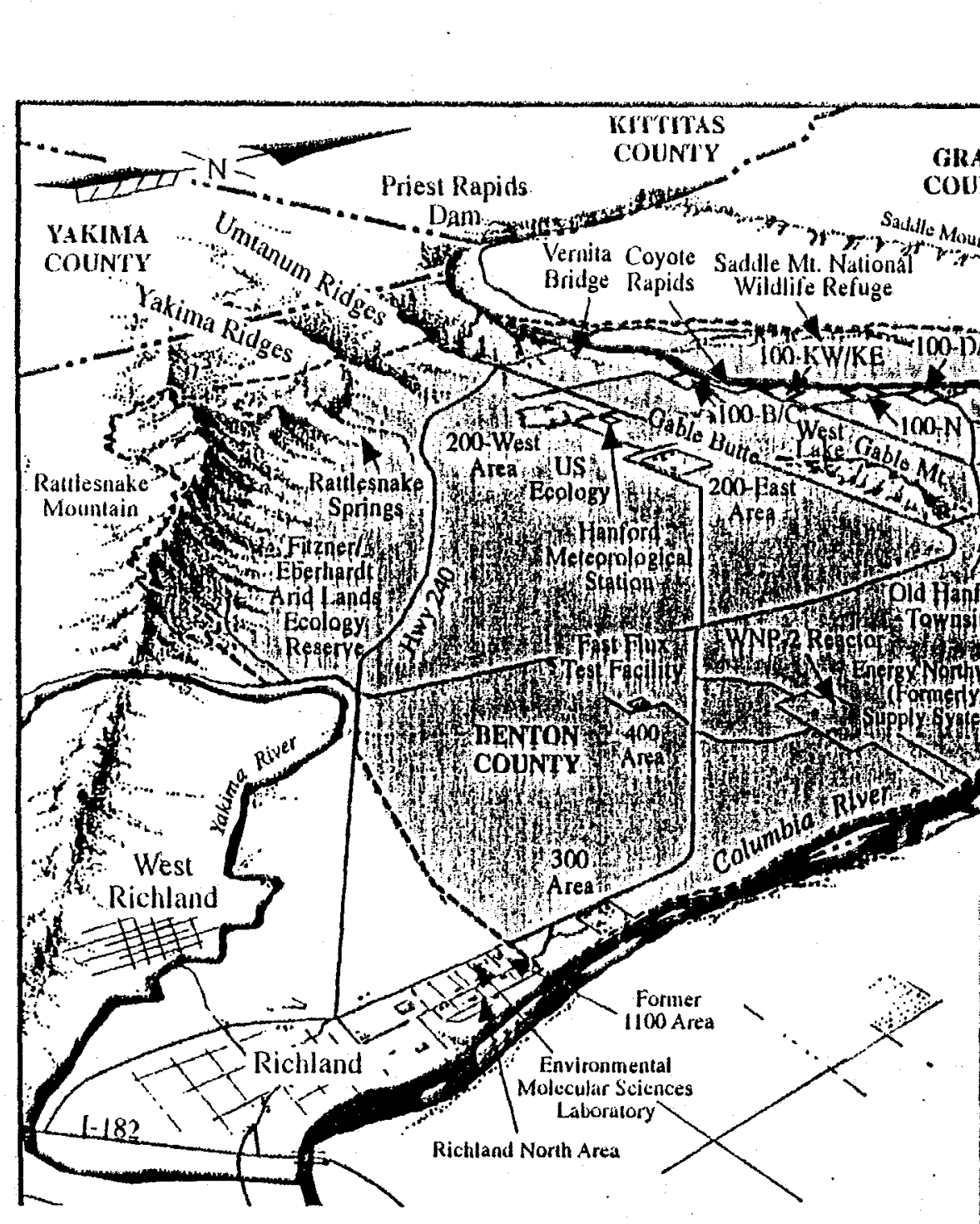

- Area of Hanford Site is $\approx 1450$ square $\mathrm{km}$

- Vegetation is mainly shrub-steppe

- Surrounding land use is range and farmland

- Columbia River is major hydrologic feature

- Major site of radiocesium contamination is 200 Area

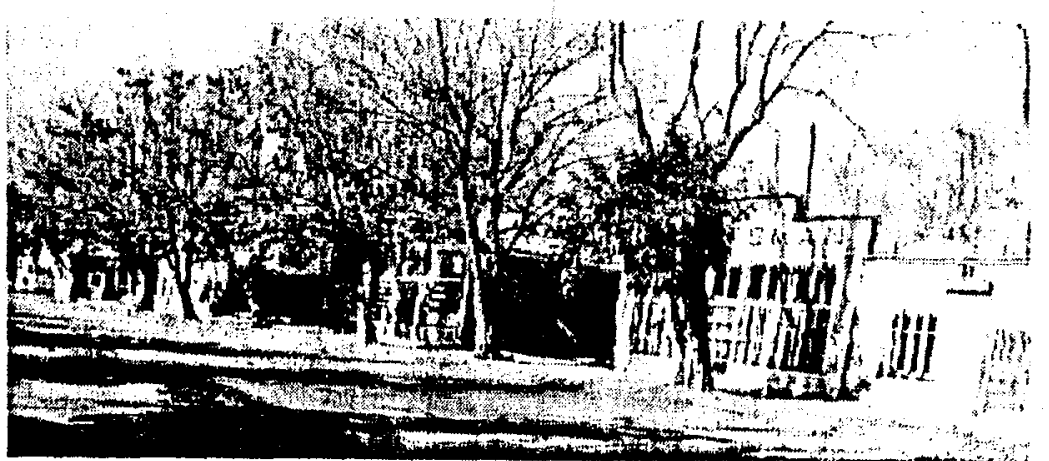

Abandoned community at Hanford 


\section{SAVANNAH RIVER SITE SETTING}

\section{Map of Savannah River Site}

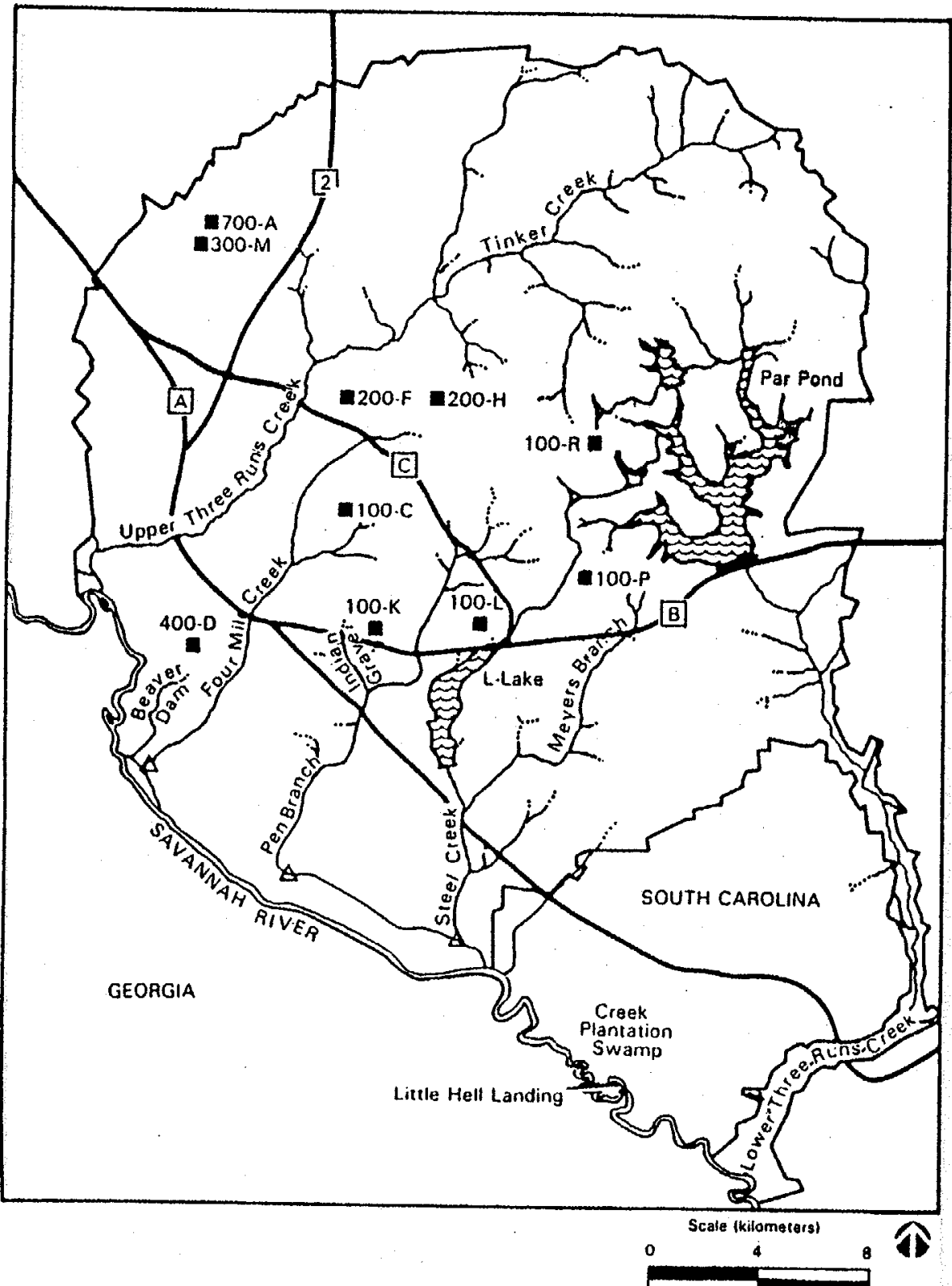

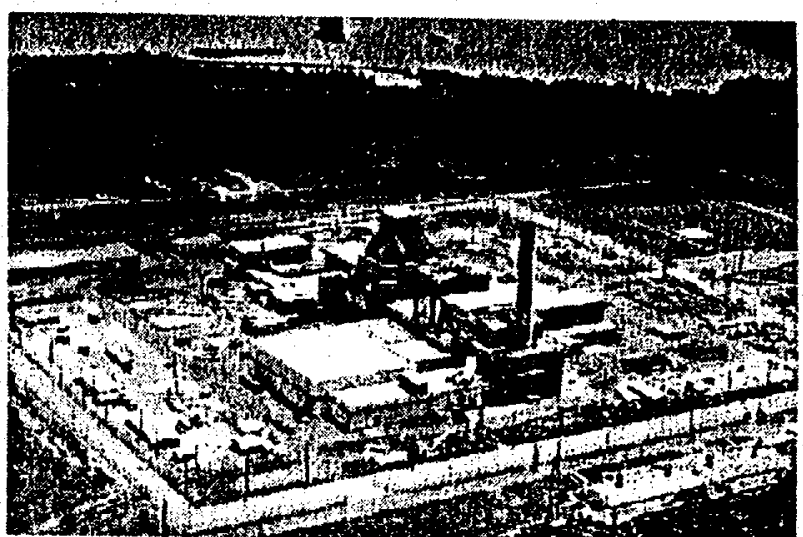

Production Reactor

- Area of Savannah River Site is $\approx 800$ square $\mathrm{km}$

- Land use prior to government acquisition was agriculture and forestry

- Vegetation is mainly mixed hardwood and coniferous forest (pine)

- Savannah River is major hydrologic feature

- Major site of radiocesium contamination is surface streams and seepage basins 


\section{CLIMATE DIFFERENCES DISTINGUISH HANFORD FROM OAK RIDGE AND SAVANNAH RIVER}

\begin{tabular}{|c|c|c|c|c|c|}
\hline Location & Climate & $\begin{array}{r}\text { Mean } \\
\text { Annual } \\
\text { Temp } \\
\left({ }^{\circ} \mathrm{C}\right)\end{array}$ & $\begin{array}{r}\text { Mean } \\
\text { Annual } \\
\text { PPTN } \\
(\mathrm{cm})\end{array}$ & $\begin{array}{r}\text { Approx. } \\
\text { Annual } \\
\text { Runoff } \\
(\%)\end{array}$ & $\begin{array}{r}\text { Annual } \\
\text { PET } \\
(\mathrm{cm})\end{array}$ \\
\hline Hanford & Cool-arid & 9.9 & 20 & 15 & $61-91$ \\
\hline Oak Ridge & $\begin{array}{l}\text { Humid- } \\
\text { temperate }\end{array}$ & 13.7 & 137 & 45 & $61-91$ \\
\hline Savannah R. & Subtropical & 17.3 & 113 & 30 & $91-122$ \\
\hline
\end{tabular}


- OAK RIDGE

- Siltstone, sandstone and cherty dolomite ridges

- Shale (Conasauga Group) and limestone valleys

- Acidic soils with a high silt-clay content (illitic clays)

- High runoff of infiltration to surface streams (aquitards)

- HANFORD SITE

- Ancient \& recent alluviums and loess over basaltic lava flow

- Soils vary from sand to silty and sandy loams

- High PET due to a cool, windy, and arid enviroment

- Little runoff of precipitation at the Hanford Site

- SAVANNAH RIVER SITE

- Sandy surface soils with little clay content (kaolinitic clays)

- Thick subsurface sediments (sands, clays, limestone)

- River swamps are a main hydrologic feature 


\section{SOURCES \& ORIGINS OF RADIOCESIUM AT OAK RIDGE}

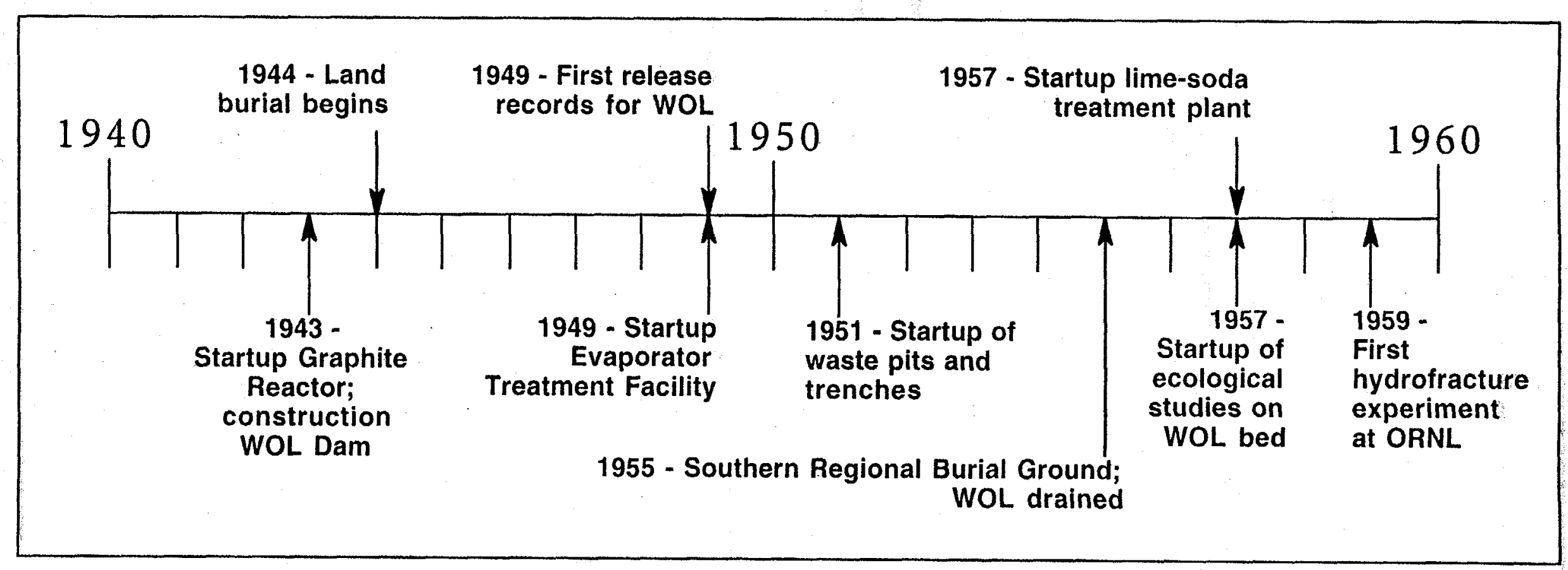

- Negligible atmospheric releases of radiocesium compared to solid and liquid radioactive waste disposal

- Impoundments (ponds, White Oak Creek foodplain, and White Oak Lake) used for settling of particle-reactive radionuclides (contain $\approx 500$ to $\approx 1800+$ $\mathrm{Ci}$ of radiocesium)

Disposal of radiocesium in solid waste at ORNL burial grounds is not known

Land disposal in pits and trenches included $\approx 640 \mathrm{kCi}$ of radiocesium 


\section{SOURCES \& ORIGINS OF RADIOCESIUM AT HANFORD}

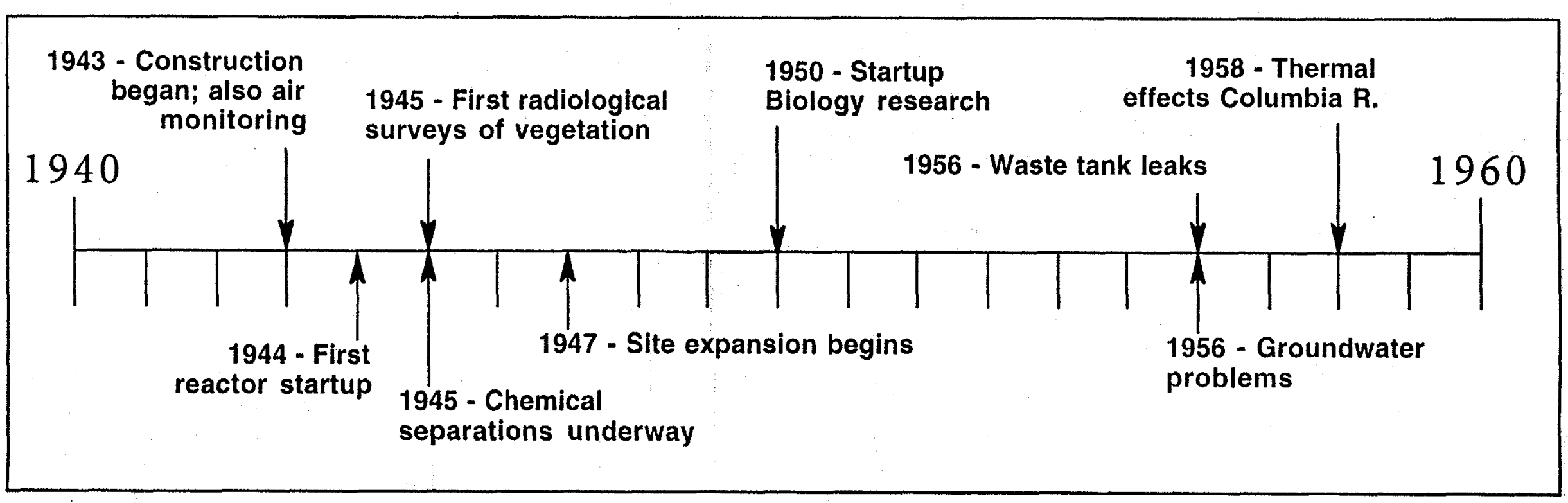

Negligible atmospheric releases of radiocesium $(\approx 42 \mathrm{Ci}$ from separations area) compared to solid and liquid radioactive waste disposal

- More than 2000 reactor fuel element failures, but leaks diverted away from the Columbia River (no estimated annual releases of radiocesium to river)

Drimary site for radiocesium was Hanford's 200 Areas that included waste disposal ponds, cribs, trenches, burial grounds, storage tanks (28 MCi)

Land disposal included a total of $\approx 40 \mathrm{kCi}$ radiocesium 


\section{SOURCES \& ORIGINS OF RADIOCESIUM AT SAVANNAH RIVER}

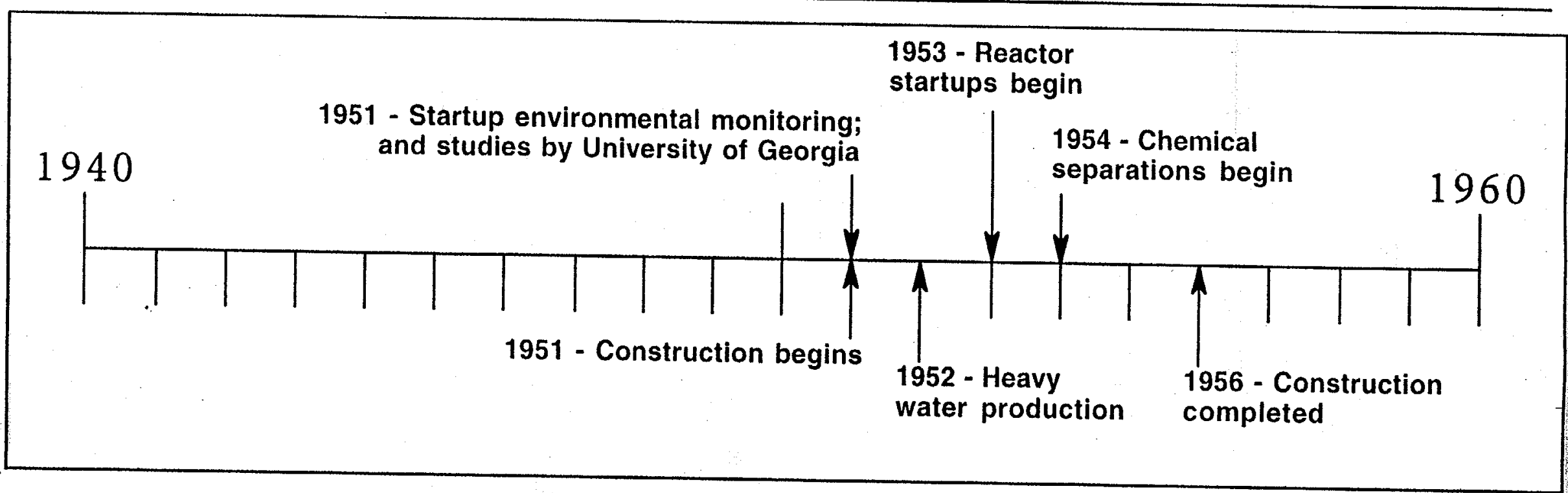

Degligible atmospheric releases of radiocesium $(\approx 3.5 \mathrm{Ci}$ from separations area) compared to releases to terrestrial and aquatic systems

- Total release of radiocesium to streams and seepage basins was $\approx 2570 \mathrm{Ci}(75 \%$ to seepage basins and 25\% to streams); $963 \mathrm{Ci}$ during the period 1955-1959

- Through 1989, total radiocesium released to streams at the Savannah River Site was $\approx 608 \mathrm{Ci}$ (most to Steel Creek, Par Pond, and Lower Three Runs Creek)

- Releases primarily from failed reactor fuel elements and purge water from fuel element disassembly basins 
RADIOCESIUM (Ci)

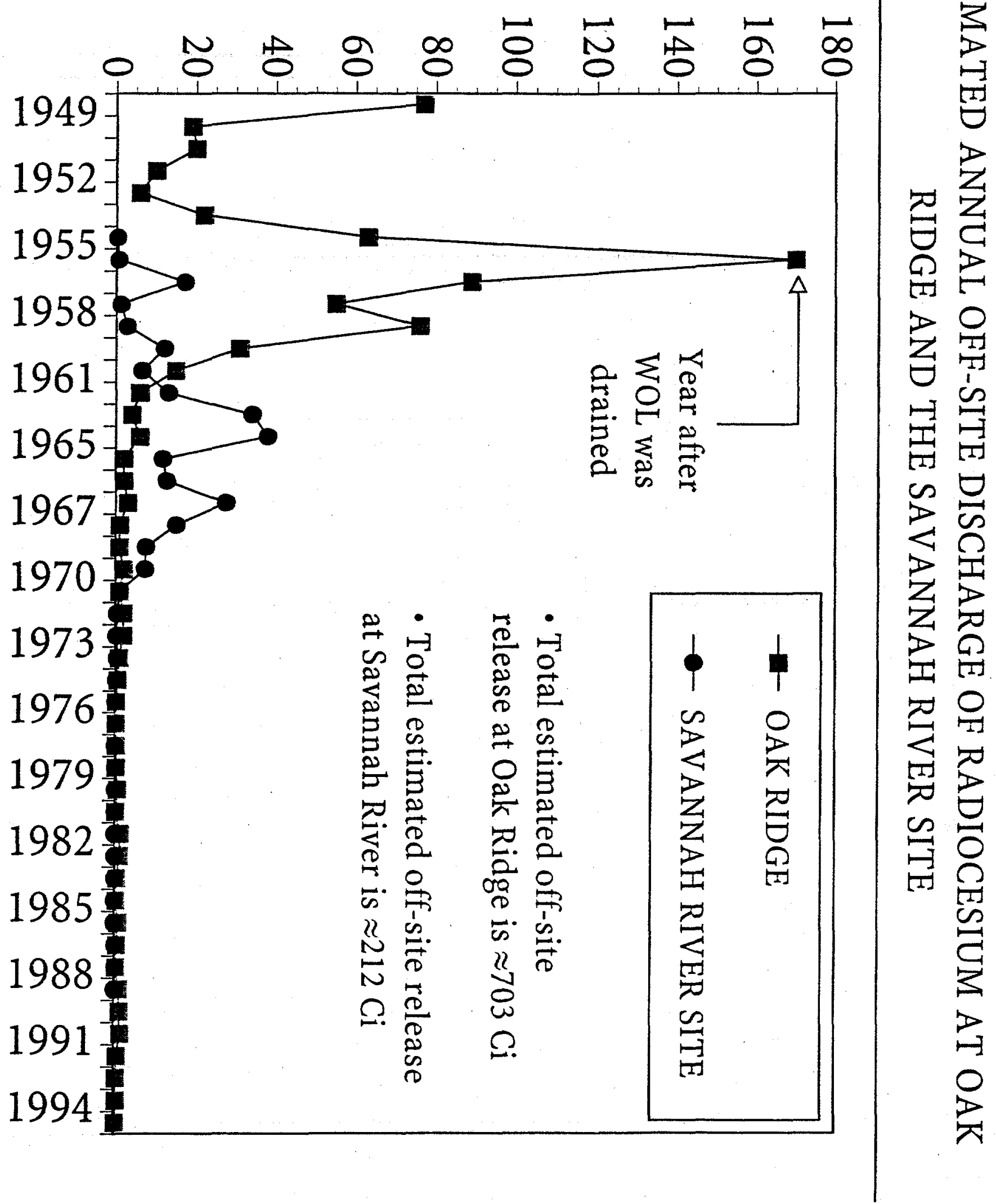




\section{EARLY STUDIES OF RADIOCESIUM FATE AND TRANSPORT}

- Environmental studies (environmental monitoring for radioactivity, biological surveys, and radioecology studies at U.S. nuclear weapons production facilities during the 1950s provide a record of early perspectives and concerns about environmental transport

- Researchers at all three sites were interested in fate and transport issues that are still investigated (even up to current times)

- radiocesium uptake by plants

- effects of soil amendments on radiocesium uptake by crops

- radiocesium transfer from plants to animals

- the potential for contaminant dispersal by wildlife

- effects of radiation exposure on plants and animals 
EARLY STUDIES OF RADIOCESIUM FATE AND TRANSPORT: Oak Ridge

- ORNL Health Physics Division conducted early environmental studies (1943-1959) in White Oak Creek Watershed

- Studies in mid-1950s indicated a high of natural soils and shales underlying White Oak Creek watershed for adsorption of radiocesium
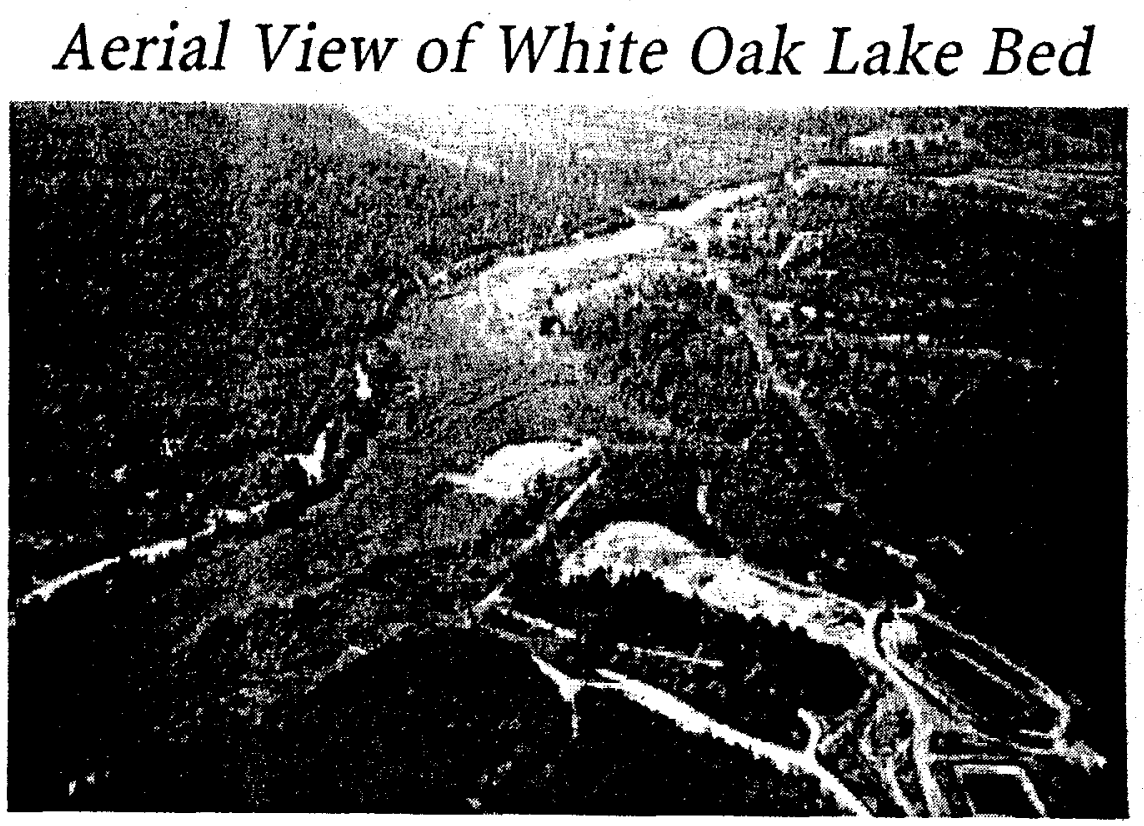

- After White Oak Lake Drained was in 1955, Auerbach et al. initiated radioecological studies on White Oak Lake Bed

- Low plant-to-soil concentration ratios for radiocesium $(\approx 0.05)$ indicating that food-chain transport was reduced at the point of soil-to-plant transfer

- Soil amendments with superphosphate fertilizer further reduced uptake by agricultural crops

- No deleterious effects of radiation exposure on plants and small mammals 
- Radiocesium contamination is isolated and relatively localized (waste disposal areas)

- Radiocesium was taken up by animals from open disposal systems (ditches and ponds) in the early days

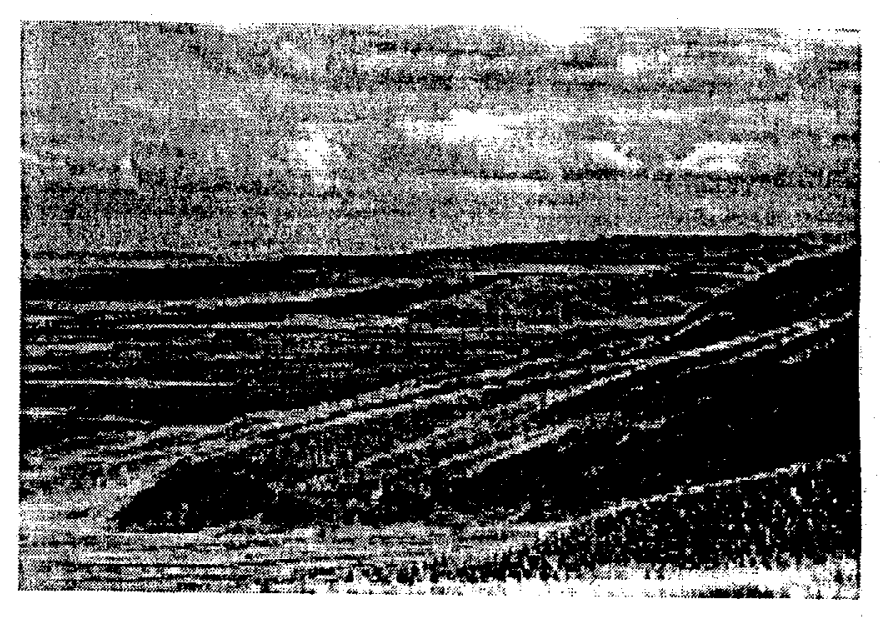

- Plant-to-soil concentration ratios ranged from 0.008 to 0.066 indicating strong sorption of radiocesium to Hanford soils

- Deep rooted desert plants transported radiocesium from the subsurface to the surface where it became available for food-chain transport

- Animals burrowed into some buried radioactive wastes (in cribs and trenches) and transported radiocesium to the surface of the ground

- Dispersal of radioactivity across the site by wind-blown tumbleweeds 
- Environmental monitoring began in 1951 -- baseline surveys of the Savannah River by the Academy of Natural Sciences of Philadelphia

- More than 600 environmental samples analyzed for radioactivity from 1951 to 1953

- Numerous studies of radiocesium in Steel Creek which received $284 \mathrm{Ci}$ from 1955 to 1973

- Relatively high plant-to-soil concentration ratios for radiocesium (1 to 10$)$

- Some radiocesium in streams redistributed by floods and erosion
MAP OF RADIOCESIUM IN PLANTS FROM. STEEL CREEK (1973)

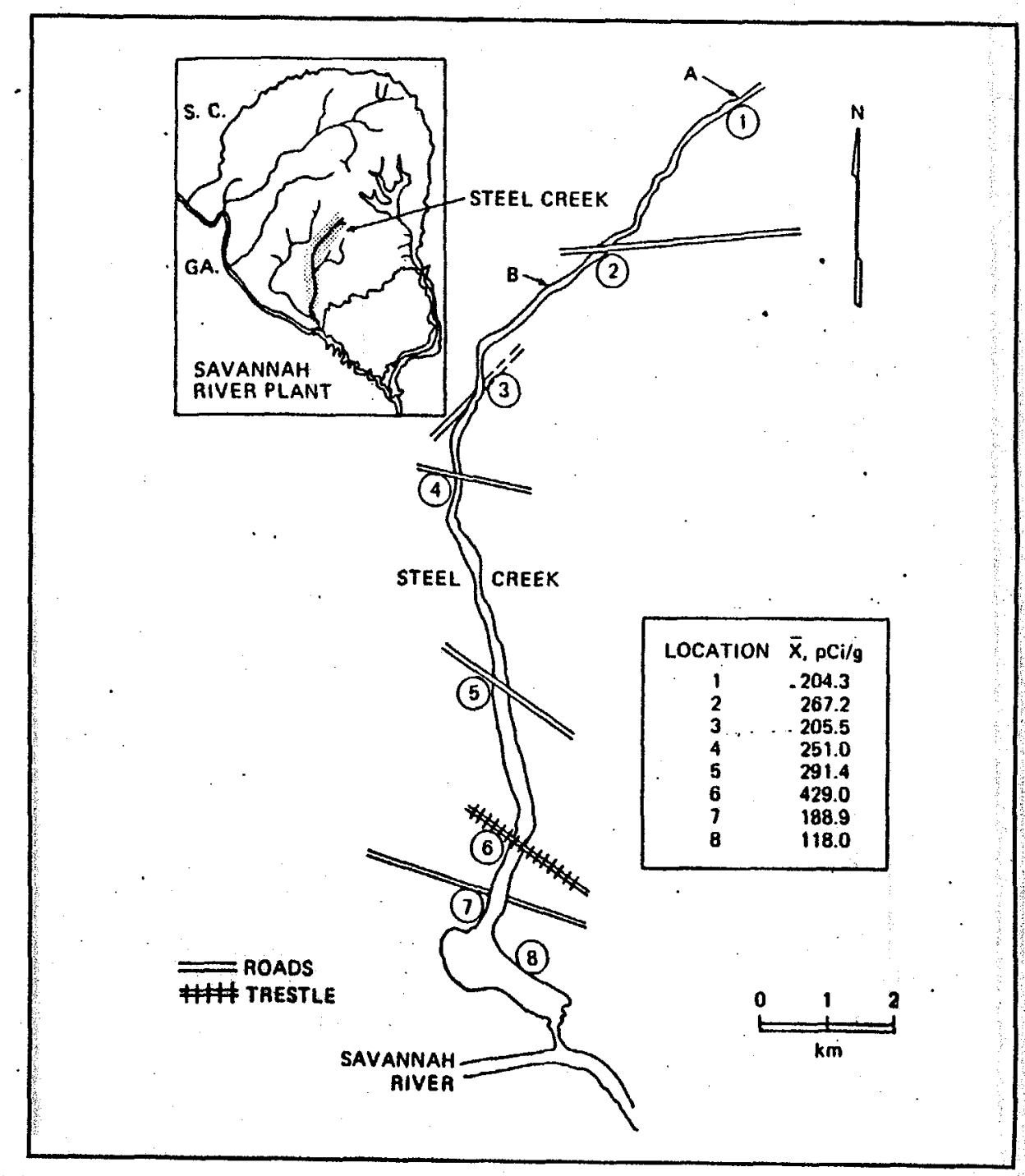




\section{"SITE RETENTION INDEX" FOR RADIOCESIUM}

SRI = Direct Releases to On-Site Environment $\div$ Total Off-Site Releases

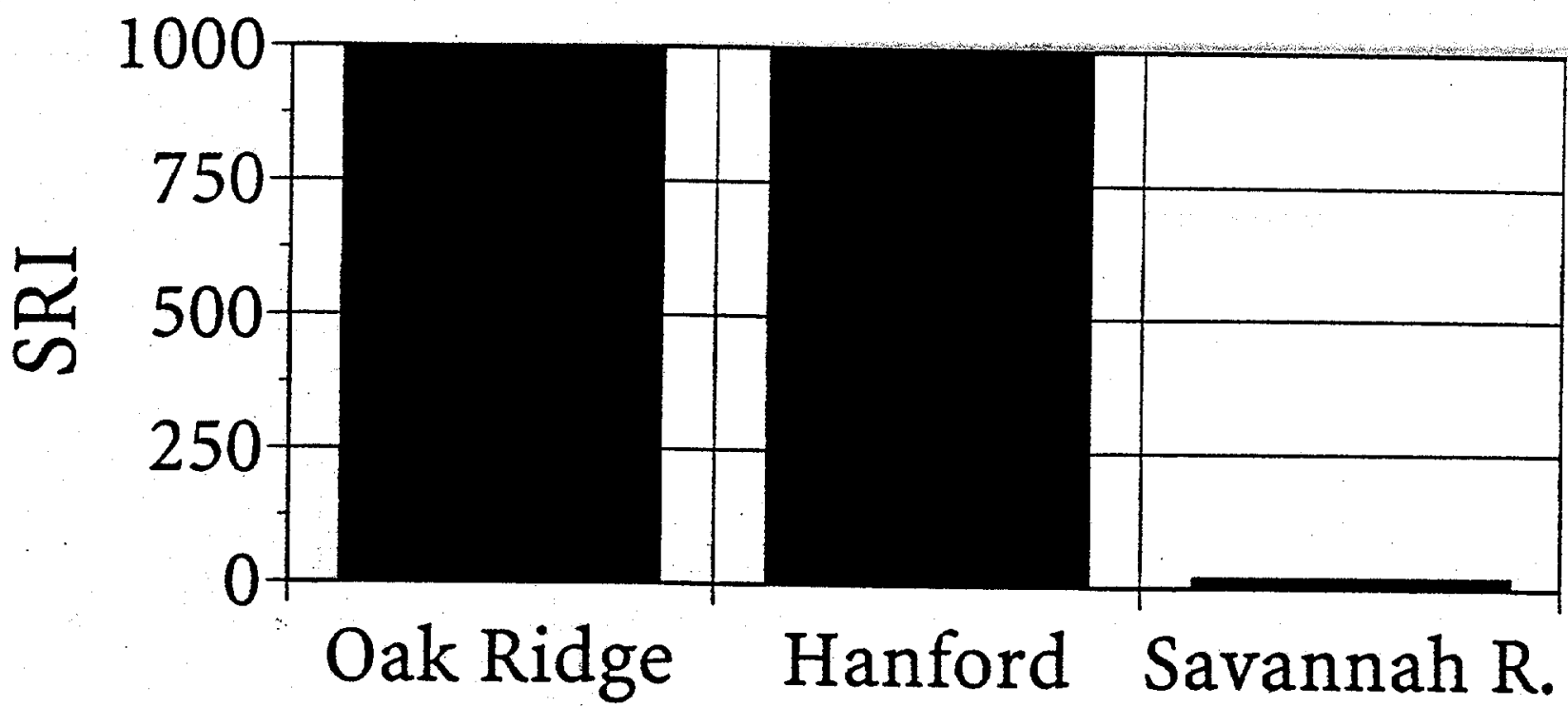

ESTIMATED

ENVIRONMENTAL RELEASES
Radiocesium Radiocesium

On-Site (Ci) Off-Site (Ci)

$O A K$ RIDGE

Impoundments

Seepage Basins (Pits, Trenches)

Hydrofracture

800
$640 \quad 000$
$684 \quad 000$

HANFORD

Atmosphere

Tank leaks

Land Disposal (Pits, Trenches)

High Level Waste Tanks

42

$40 \quad 000$

$40 \quad 000$

$28000 \quad 000$

SAVANNAH RIVER SITE

Atmosphere

Streams

Seepage Basins (Pits, Trenches)

Solid Waste Disposal

High Level Waste Tanks

1809 
CONCLUSION: Siting of U.S. Weapons Facilities Helped Minimize Environmental Transport of Radiocesium

- High fission yield and ease of detection made radiocesium a prime candidate for radioecological studies during the $1950 \mathrm{~s}$

- High site retention of radiocesium at Oak Ridge, despite large releases directly to the environment, is due to strong fixation by illitic clay minerals (i.e., geological factors)

- Geology \& climate contribute to high site retention at Hanford

- Lower site retention index and greater environmental mobility of radiocesium at the Savannah River Site is due to poor fixation by kaolinitic clay minerals in sandy soils (i.e., geology)

- Despite no formal consideration of radioecology and environmental assessment during facility siting, there has been relatively little off-site transport of radiocesium at Oak Ridge, Hanford, and the Savannah River Site since the 1950s 